\title{
Analysis of Regulatory Structure for a Potential Fusion Reactor Industry
}

Donovan, Hamester \& Rattien, Inc.

March 1981

Prepared for

Pacific Northwest Laboratory

Under Agreement B-A5868-A-P

Pacific Northwest Laboratory

Operated for the U.S. Department of Energy

by Battelle Memorial Institute 


\title{
NOTICE
}

This report was prepared as an account of work sponsored by the United States Government. Neither the United States nor the Department of Energy, nor any of their employees, nor any of their contractors, subcontractors, or their employees, makes any warranty, express or implied, or assumes any legal liability or responsibility for the accuracy, completeness or usefulness of any information, apparatus, product or process disclosed, or represents that its use would not infringe privately owned rights.

The views, opinions and conclusions contained in this report are those of the contractor and do not necessarily represent those of the United States Government or the United States Department of Energy.

\author{
PACIFIC NORTHWEST LABORATORY \\ operated by \\ BATTELLE \\ for the \\ UNITED STATES DEPARTMENT OF ENERGY \\ Under Contract EY-76-C-06-1830
}

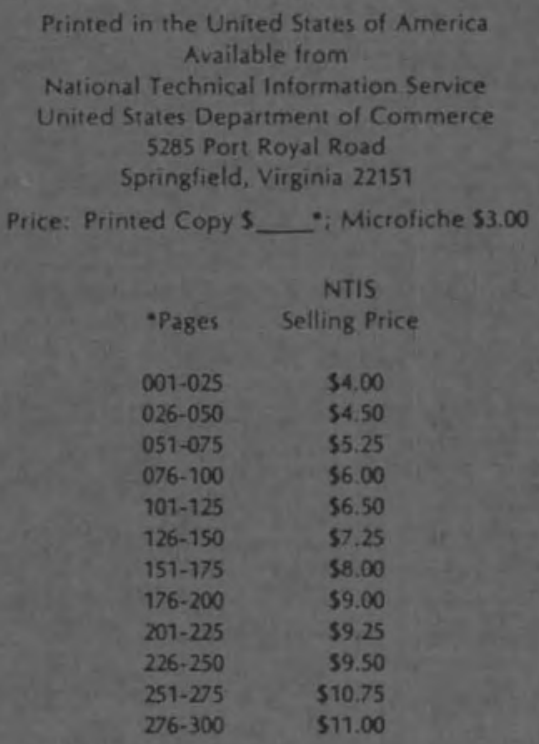


PNL -3685

ANALYSIS OF REGULATORY STRUCTURE FOR A POTENTIAL FUSION REACTOR INDUSTRY

Donovan, Hamester \& Rattien, Inc.

March 1981

Prepared for

Pacific Northwest Laboratory Under Agreement B-A5868-A-P

Pacific Northwest Laboratory

Richland, Washington 99352 
TABLE OF CONTENTS

Page

PREFACE

SUMMARY

SUMMARY TABLE VIii

Flow Chart for Proposed Regulatory Model x

Flow Chart for Present NRC Regulatory Procedures xi

I. INTRODUCTION 1

A. Energy Policy 1

B. Existing Regulation of Energy Sources 3

C. Scope of Report 4

II. TYPES OF REGULATIONS 6

A. Dedicated Federal Entity vs. Multi- 6

Layered Federal Regulatory Approach

B. The Appropriateness of a Multi-Layered 20

Federal Approach as a Model for a Fusion

Reactor Regulatory Structure

C. Regulation by an Independent Regulatory 25

Commission Versus an Executive Agency

for the Case of a Dedicated Regulatory Entity

III. THE NUCLEAR REGULATORY COMMISSION 31

A. History of the NRC 31

B. Scope of Authority and Internal Organi- 34 zation of the NRC

C. NRC Licensing Procedures 36

D. NRC Hearing Procedures 39

E. Judicial Review of NRC Orders 40

F. Limited Work Authorizations 41

G. Critiques of the NRC 42

H. Public Perception of the Risks of 43

Nuclear Power and its Regulators

I. The Kemeny Commission 46

J. Criticism of NRC Design Basis Review 51 
K. Summary of Criticism of the NRC 55

IV. CONSIDERATIONS RELEVANT TO A FEDERAL 60 AGENCY FOR THE REGULATION OF FUSION REACTORS

A. Relevant Technical Aspects of Fusion 60

B. Adjudiciary Considerations in the 64 Regulation of Fusion Power

c. One Process Considerations in the 66 Permitting Process

D. Recommended Permitting Approach,

E. Probabilistic Analysis and Rulémaking Procedures

V. RECOMMENDATIONS TI

$\begin{array}{ll}\text { VI. CONCLUSIONS } & 75\end{array}$ 


\section{PREFACE}

This report seeks to develop a regulatory model for effective governmental oversight of a fusion reactor industry. Its principal author was Judge Joseph Cohen, an administrative law judge for the Pennsylvania Public utility Commission. Technical advice and expertise in the preparation of this report was supplied by Drs. Hans Hamester and Richard Silberglitt of DHR. Research into environmental law and energy regulation was done by William Floyd-Jones, Ir.

The proposals contained herein were developed after a careful study of the existing systems for regulating sources of electric energy. To this end, the DHR team carefully reviewed the major pieces of federal legislation affecting the generation of electricity: The Clean Air Act, The Federal Water Pollution Control Act, The Federal Power Act, the Atomic Energy Act, and The National Environmental Policy Act. Within the scope of these statutes we particularly focused upon the promulgation of regulations under Executive order 12044, the structure of the various permit systems, and, most importantly, the processes established by each of these major federal statutes for the regulation of their respective technologies.

After reviewing the success, or lack thereof, of the existing regulatory systems, the DHR team devised the proposed regulatory model. Our overriding concern in developing this 
model was to provide for the most expeditious licensing of fusion reactors that would be consistent with the protection of public safety and health. In addition, we gave particular attention to developing meaningful opportunities for public participation in the regulatory process since we believe that the timetable for developing a fusion reactor industry may depend upon public acceptance of this new technology. We believe that the avenues for public participation we propose will improve the quality of regulatory decisionmaking and, at the same time, will not lend themselves to dilatory tactics.

Throughout this report, two terms from administrative law will continually appear; they are "rulemaking" and "adjudication." Rulemaking refers to the process of promulgating regulations establishing standards of future conduct of general applicability. Under traditional rulemaking procedures, an agency is required to give public notice of proposed regulations of general applicability in the Federal Register. Interested persons then have the right to submit written comments on the proposed regulations prior to final agency adoption. Under this procedure there is no trial type hearing and the agency decision is not on the record, i.e., the agency need not base its decision solely on the written comments submitted, but may take into account any information it deems fit. The agency is required, however, to give a "concise general statement of the basis and purpose" of its action. An adjudicatory proceeding is a trial type hearing in which agency staff and any affected private parties have the right to 
introduce direct and rebuttal evidence through live witnesses and exercise the right of cross examination. The agency's ultimate decision is required to be based on the evidence developed at the hearing and must ordinarily take the form of an opinion which discusses the evidence and makes relevant factual findings. Such a hearing is often required under regulatory statutes in cases where the agency takes individual enforcement action or seeks to impose sanctions on particular parties. Courts also have found that adjudicatory proceedings are required by constitutional due process when an individual is deprived of property, a right, or some entitlement (e.g., a permit).

The report is divided into eight sections. The preface describes the authors of the report, the methodology used in its preparation, and some basic legal terms. The summary describes the principal features of the proposed regulatory system and also includes two flow charts comparing our model with present NRC practices and a summary table briefly outlining the reasoning behind our recommendations. The main body of the report is divided into six sections. This part of the report discusses the existing federal and state programs for regulating electric energy, describes NRC operations and the criticisms of that agency, discusses the features of our proposed regulatory model, recommends certain steps for implementing the proposed model, and states the conclusions of the report. 
Finally, we note that the regulatory model proposed in the text of the report has the flexibility to be implemented via a conventional Federal agency, a commission, or a hybrid structure. In various places in the text the word "agency" is used to denote any of these possibilities. However, throughout the Summary and the Recommendations and Conclusions sections of the report the word agency is used only in the conventional manner. 


\section{SUMMARY}

The purpose of this report is to suggest the outlines of a regulatory system for the oversight of commercial fusion reactors. We believe that the system herein proposed will provide for the expeditious licensing of fusion reactors, create opportunities for meaningful public involvement in the licensing of these reactors, and establish a regulatory body whose structure and processes permit effective oversight of the industry.

The principal features and recommendations of our proposed regulatory model are as follows:

(1) Even though a careful reading of the Atomic Energy Act of 1954 indicates that the NRC does not have regulatory jurisdiction over fusion reactors, both that Act and the Energy Reorganization Act of 1974 should be explicitly amended to preclude the NRC from exercising jurisdiction over commercial fusion reactors.

(2) We recommend the creation of a regulatory structure in which the administrative and enforcement authority are vested in a single individual who serves at the pleasure of the President, with appointment of this individual subject to the advice and consent of the senate. This regulatory structure should be within the Executive Branch of government and could either be an administrative agency, a commission whose chairman is the single individual described above, or a hybrid structure in which the Executive Agency has an advisory board attached to it. In either of the latter two cases the board or commission would have no administrative or enforcement powers, but would play a significant role in the formulation of regulatory policy and the adoption of rules and regulations. This board or commission would consist of members appointed by the President with the advice and consent of the senate to serve fixed but staggered terms, and could allow the balancing of political interests found in many existing independent regulatory commissions. 
However, the power vested in the single individual should allow for more efficient administrative practices, provide for more meaningful enforcement, facilitate the formulation of long range policy and make the proposed structure somewhat more responsive to the political process, as compared with the present situation with fission reactor regulation.

(3) We recommend the creation of an Administrative Review Board to review the decisions that grant, deny, modify, suspend, or revoke permits. Administratively, the Review Board would be separated from the rest of the regulatory structure. This structuring would eliminate the ex parte communications problems that now hamper the NRC. We propose only one level of administrative review, in contrast to the three review levels now found in NRC procedures. This shortening of the administrative review process should not adversely affect the quality of decisions and at the same time would greatly shorten the adjudication process.

(4) The report assumes that there will be only one, or perhaps two, standardized reactor designs. We propose that after the testing of a prototype commercial fusion reactor, there should be rulemaking proceedings to determine generic design and siting criteria for commercial fusion reactors. These generic rulemaking proceedings should be based upon the Executive order 12044 model for rullemaking. Consideration should be given to funding intervenors at these proceedings. It is essential that the rulemaking be as open as possible to ensure that the public health and safety is adequately protected and also to ensure that all segments of the concerned public perceive that the regulatory structure is responsive to its interests.

(5) We recommend the granting of a construction permit if, after a thorough review, the regulatory technical staff feels that the proposed reactor is both safe and in the public interest. There would be no adjudicatory proceedings prior to the grant of the permit although a person with standing might petition the Review Board for a stay of the permit if they believe that the reactor would violate federal health or environmental standards on account of site specific circumstances. The petitioner in such proceedings would carry the burden of proof in showing that compliance with the generic regulations in 
the specific case is insufficient to achieve the health and safety requirements of the Act. The generic regulations, themselves, would not be subject to challenge in such a hearing. Since a thorough review of the permit application will have been made prior to any adjudication, the quality of the Review Board's decision should be enhanced.

(6) We recommend against any operating permit procedure since the public health and safety should be adequately protected by the initial construction permit review. If new information is discovered subsequent to the grant of a construction permit as to unacceptable impacts from the reactor, the public health could be protected by modifications in the plant design, "ratcheting" of standards, or revocation of the permit.

(7) Within the proposed regulatory model, modifications to reactor design or ratcheting of standards subsequent to the grant of the construction permit would only be ordered by the single individual vested with adninistrative authority (or certain statutorily enumerated delegates) in order to protect the public health and welfare. The utility could challenge such orders before the Administrative Review Board. The utility would carry the burden of proof in such proceeding to show that the original design was sufficient.

(8) Under the proposed system, a permit could not be suspended or revoked without prior notice to the utility of the reasons therefore and a subsequent opportunity for the utility to challenge the action before the Review Board.

(9) Consideration should be given to funding petitioners and intervenors in all rulemaking and adjudication. In our view, this could be an important feature of a strategy to ensure public acceptance of the proposed regulatory structure.

(10) As is the case with the NRC, the Administrative Review Board would consist of one attorney and two technical experts. 


\section{Recommendations}

1. Establish a regulatory structure headed by a single individual within the Executive Branch of the Federal Goverrment to regulate the fusion reactor industry.
2. Develop generic design criteria for fusion reactors based upon interaction with the decision process of a commercial prototype.

3. Encourage public participation in rulemaking and licensing by employing the rulemaking model suggested in Executive order 12044 and giving consideration to funding intervenors.

4. Establish a one step licensing process by eliminating any operating License requirement.

\section{Reasons}

a) Single Federal entity approach is simpler and more effective than a multi-layered Federal approach (see text for details).

b) Placing the regulatory structure within the Executive Branch would increase its accountability and responsiveness.

c) Eliminating the collegial decision making found in a regulatory commission would ease policy formulation and increase administrative efficiency. Balancing of political interests could be obtained via a board or commission without administrative authority.

Would protect the public health and safety while speeding the technical review of a proposed reactor and narrowing the issues at any adjudication on a licensing decision.

Would improve the credibility of the new regulatory structure among members of the concerned eublic and would also improve the quality of decisions by opening them to outside input.

Would speed and simplify the licensing process with no adverse consequences to the public health and safety. 
$\underline{\text { Recommendations }}$

5. Grant or deny a permit after a thorough review by the regulatory technical staff.

6. Establish an Administrative Review Board that is separate from the rest of the regulatory structure to hear all adjudications.

7. Provide for only one level of adjudicatory review within the regulatory structure.

8. After a permit has been granted, a modification in plant design would only be ordered by the single individual vested with administrative authority (or a statutorily enumerated delegate).
Reasons

Would speed the licensing process and improve the quality of the Review Board's decision by subjecting every application to a thorough technical review prior to any adjudication.

Would eliminate the ex parte communications problem that presently hampers NRC activities.

Would simplify the licensing process, reduce the opportunities for administrative delay, and, at the same time, would not affect the quality of decisions.

Would increase accountability by placing the responsibility for costly and important decisions upon the shoulders of a clearly identifiable person. Would also replace an Operating Permit as a means for the regulation of fusion reactors in the interest of the public health and safety after the grant of a permit. 
PROPOSED REGULATOHY MODEL

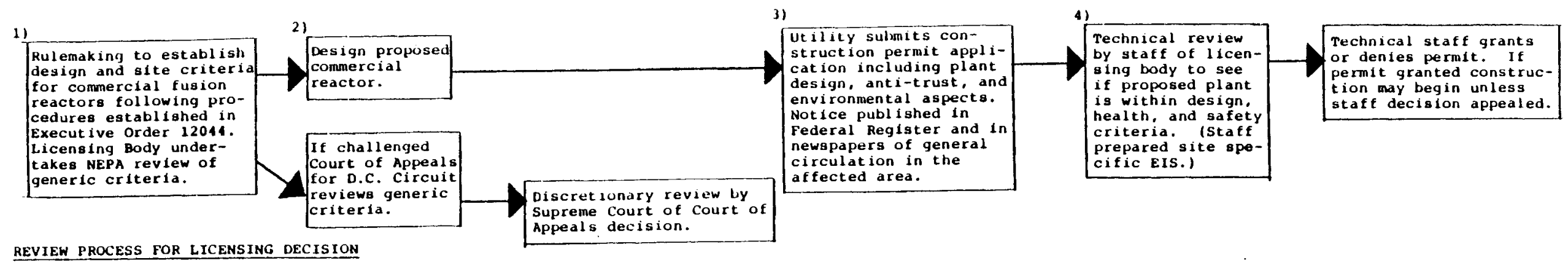

REVIEW PROCESS FOR LICENSING DECISION

art of

Appeals decision.

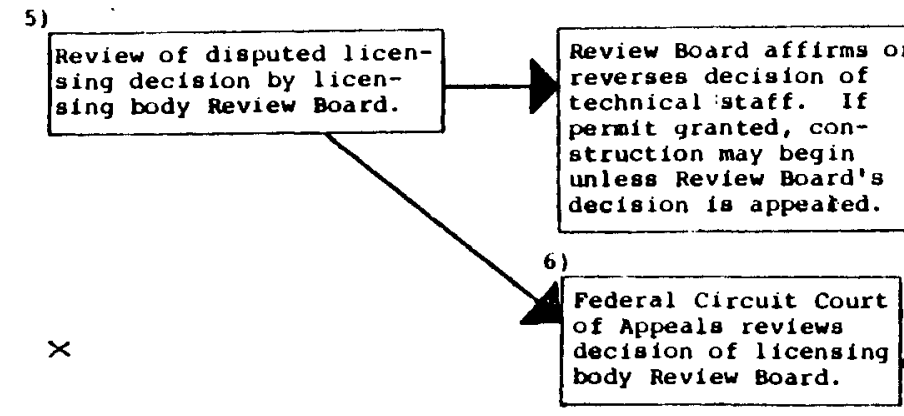

ENFORCEMENT

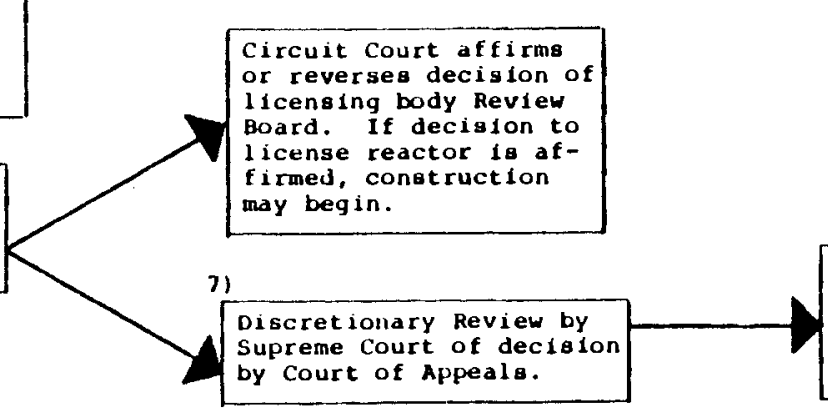

Supreme Court af $f$ irms or reverses decision to license court. Ir is af i irmed, construction may begin.

Three enforcement strategies for different hazards B)

Administrative Head of licensing body orders immediate halt to operation of plant if continued operation constitutes a severe and 1 mminent hazard to the public
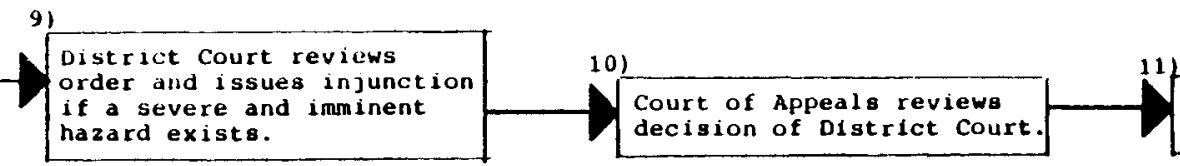

Discret lonary review by
Supreme court. hazard exista. health and safety. On complaint of licensing body or state enforcement agency Review Board may assess civil penalties fo violation of licensing body's enabling statute or regulations.

Administrative Head of licensing body orders change in plant operation or design to protect public health and safety.
Court of Appeals reviews Court of Appeals reviews
decision to penalize utility.

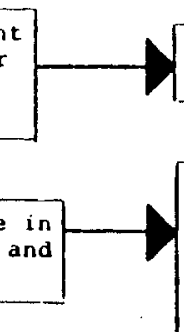
Utility appeals to licensing
body Review boda. Utility has burden of proof to show modifications a re not necessary to protect public health and wel fare.
Discretionary review by Supreme Court
sion.

Court of Appeals reviews

decision of Review Board. 
NRC PROCEDURES

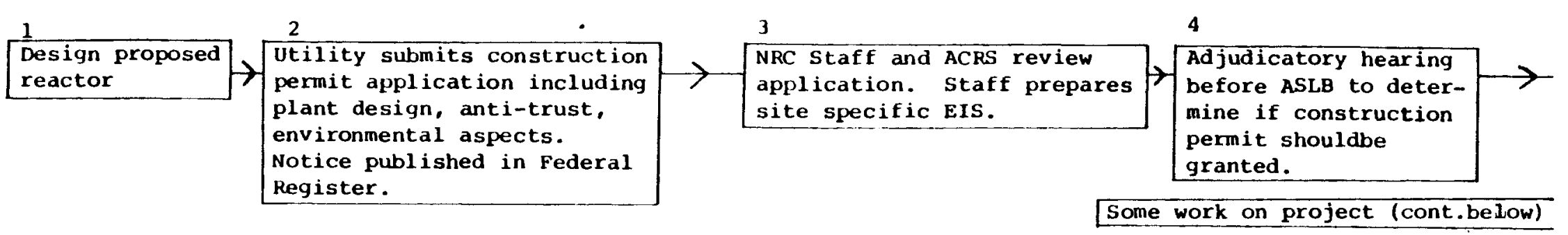

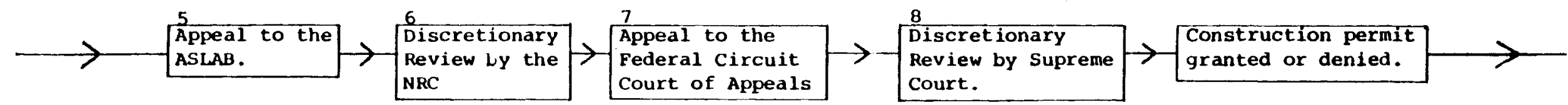

proceeds under a limited work authorization

メ.
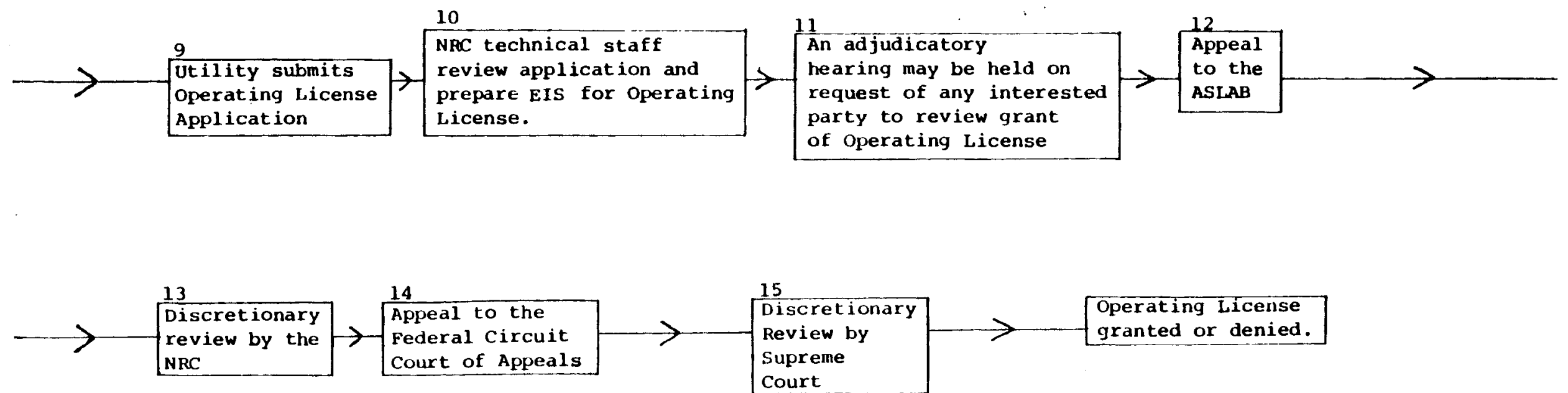

"ANALYSIS OF REGULATORY STRUCTURE FOR A POTENTIAL
FUSION REACTOR INDUSTRY"

I. INTRODUCTION

A. Energy Policy

The energy crisis, with its attendant national security, economic and social implications, has stimulated interest in the development of technologies that are intended to reduce this country's dependence upon foreign energy sources and thereby create a substantial measure of energy independence for this country. It cannot be denied that the future of this country is dependent upon the development of internal energy resources that are not subject to the international political demands of our foreign energy sources. Thus, we have developed national programs to encourage both energy conservation and the development within this country of existing and novel sources of energy. It is within this context that substantial interest has been focused upon fusion reactor technology.

It is estimated that the commercial availability of fusion reactors is at least 20 years into the future. Meanwhile, the Energy Research and Development Administration (ERDA) and then the Department of Energy (DOE) have undertaken and sponsored research into the development of commercially viable fusion reactors. To complement the scientific research in this field, it is appropriate to study existing governmental regulatory practices to ascertain an appropriate structure for the regulation of a potential fusion reactor industry. It is not sufficient, however, merely to ascertain the appropriate regulatory structure for the oversight of fusion reactors onck 
placed into commercial operation. It is also necessary to elaborate the processes that will be employed within the regulatory structure to accommodate legislatively articulated public policy objectives.

The structure and process of government regulation raise issues of law and public administration. The regulation of a new technology to accommodate energy needs, for example, requires that law and public administration take into consideration the dynamics of the technology in question. Otherwise, the regulatory structure and process will respond poorly to the unique problems posed by the new technology. Thus, it is necessary for the process and structure of regulation for commercial fusion reactors to respond to imperatives of that science. Otherwise, the regulatory system will not be able to accomodate any adverse consequences of the new technology.

The current commitment of substantial governmental funds and efforts into the research and development of fusion technology indicates a public policy decision to ascertain the feasibility of fusion reactors for the commercial generation of electricity. The enactment into law of a regulatory structure for the control of fusion reactors presupposes a public policy to encourage the commercial operation of such reactors consistant with certain regulatory objectives. This must be stated at the outset since there is much debate as to whether promotional and regulatory activities should be combined in one governmental agency.

The passage of the energy reorganization act of 1974 , which abolished the Atomic Energy Commission (AEC) and conferred upon separate agencies its regulatory and promotional functions, was 
premised upon the undesirability of one agency having the apparently inconsistent responsibilities of promoting and regulating the fission reactor industry. The fact of the matter, however, is that Congress, originally conferred upon the AEC explicit promotional and regulatory responsibilities. More importantly, even had Congress never explicitly conferred upon the AEC promotional responsibilities, the very nature of the permitting and licensing process, in our opinion, would have contained an implicit developmental or promotional orientation. To assume that a highly capital intensive industry such as the nuclear reactor industry can be regulated by a governmental agency without that body acquiring some degree of developmental and promotional orientation is to invite expectations that lead to the kind of disillusionment that caused the demise of AEC. Thus, it is essential to take into account the likelihood that a regulatory structure with no explicit Congressional mandate to promote the utilization of fusion technology may, nevertheless, develop a promotional orientation to some extent. It is necessary for policy makers expressly to recognize this tendency rather than to assume that an agency with an exclusive regulatory mission will avoid those problems that afflicted the AEC and its successor, the Nuclear Regulatory Commission (NRC).

B. Existing Regulation of Energy Sources The generation of electricity is presently acomplished primarily through the utilization of hydro power, fossil fuels, and nuclear fission. Only in the case of fission reactors and hydropower 
does the federal government directly regulate the facilities used to produce electrical energy. The facilities that consume fossil fuels are not regulated directly by either the federal or state governments other than as sources of environmental pollution. There is no license or permit required for facilities using fossil fuels that is specifically related to their function of generating electricity.

Whenever a utility raises construction funds through the increase of securities, it typically must receive authorization from the state commission regulating utilities to issue such securities. To the extent that such approval is not perfunctory in nature, it is possible that such fossil fuel power plants may be subject to scrutiny by a state governmental agency for reasons specifically related to their function as producers of electric power. The same is true regarding the issuance of securities for the construction of nuclear facilities.

C. Scope of Report

This report will give consideration to the following:

(1) dedicated federal entity vs. multi-layered federal regulatory approach; (2) an independent commission vs. an executive agency as the regulatory model if a dedicated federal regulatory entity is to be preferred; (3) the role of actual and perceived risk in determining the regulatory structure ultimately selected.

In addition to the foregoing, the report will consider to what extent compliance with the requirements of the National Environmental Policy Act (NEPA is appropriate to fusion reactor regulation, the nature and extent of rulemaking and adjudication in the 
regulatory process, and the necessity to include provisions for permits and licenses in the regulatory process. Finally, the report will consider the question of public participation and intervention. These latter issues will be considered within the context of rule-making and adjudicatory procedures.

After reviewing the foregoing issues, the report will make recommendations as to the appropriate regulatory structure and process applicable to fusion reactors. In so doing, it will consider the applicability of generic regulations(1) regarding design criteria with specific reference to the present fission reactor accident criteria. In this regard, the report will discuss whether it is appropriate for the legislation establishing a regulatory structure to include specific provisions regarding design accident criteria. The recommendations will also consider whether there should be, as now exists with regard to fission reactors, a two step licensing process with one permit authorizing construction and the second authorizing commercial operations with an operating license.

The recommendations will assume that meaningful public participation at the rule-making stage is essential to public acceptance of a regulatory regime intended to meet energy needs. The regulatory process must provide for input by interested groups so that the public is assured that their health, safety, and important environmental values are protected. The recommendations will also assume that it is possible to have meaningful intervention into adjudicatory processes based upon established rules regarding

(1) A generic regulation is a regulation that establishes the standard of conduct for an entire class of activity. 
standing (1) that are consistent with nondilatory and expeditious adjudicatory determinations.

\section{TYPES OF REGUIUATION}

A regulatory structure for the fusion power industry could take many forms. In addition to regulation of matters relating to the environment, public health and safety, occupational hazards, and national security concerns, such regulations also could become a mechanism of federal preemption over other aspects of the fusion power industry, such as utility regulation. This study does not intend to address matters of national defense or security or utility regulation, but to limit its scope to matters of environmental and occupational health and safety. By doing so it does not imply that the other areas of regulation are not important, but only to stress that such a comprehensive approach would exceed the Iimitations of this study.

A. Dedicated Federal Entity vs. Multi-Layered Federal Regulatory Approach

1. Utility Regulation

Regulation of electric generating facilities can be divided into two categories. The first is economic and it concerns both rate regulation and oversight of the quality of service. The second is to protect the environment and the health and safety

(1) Standing is a legal concept that defines who may bring a lawsuit challenging a government action. In order to have standing, an individual must suffer an injury to a statutorily or constitutionally protected interest. 
of both the public and employees of the facilities. With regard to fission reactors, government. requlation also includes considerations. of rational security.

Electric utilities are subject to economic and financial regulation by both the states and Federal Government. State utility commissions regulate such matters as electric rates, service and other financial matters relating to retail electric service. The Federal Energy Regulatory Commission (FERC) has juridiction over wholesale electric rates.

The regulation of rates involves the setting of an allowable rate of return that is consistent with constitutional limitations upon the government's right to deprive a person of property without due process of law. A host of Supreme Court cases from Smyth VS. Ames, 169 U.S. 466 (1898), to Federal Power Commission vs. Hope Natural Gas Co., 320 U.S. 591 (1944), have elaborated constitutional principles applicable to rate making.

A utility is entitled to earn a rate of return on its property that is used and useful in providing the utility's service. In the case of electric utilities, generating facilities fall within this category. Prior to placing such a facility into service(l), the general rule is that except for land held for future use, construction work in progress does not become part of the utilities' rate base, and hence, is not entitled to be considered as used or useful property on which an allowable rate of return is computed. Thus, funds raised for the purpose of

(1) Placing into service reans putting the facility into operation. 
expanding plant facilities result in the incurrence of capital costs, the recoupment of which is deferred until the plant is placed in service. During the construction period, an allowance for funds used during construction (AFDUC) is credited to plant construction accounts and is added to the original cost of construction upon which the utility is allowed a return once the facility is placed into service. AFDUC is an inputed rate of return on funds, used in construction.

The fact that electric generating facilities (and especially reactors) take several years to construct and bring onto line usually means that an electric utility incurs substantial capital costs over a long period without the ability to recover them prior to the plant's initial operation. The fact that the original cost of a new facility is enhanced during the period between the initial raising of funds for construction and the ultimate operation of the facility by the accural of AFDUC does not really mitigate the financial risks to which an electric utility is exposed during this time. In fact, in the case of fission reactors the period between raising the capital for the construction of such facilities and their ultimate operation may expose the utility to substantial financial instability. As the experience of TMI II indicates, the removal of a nuclear fission reactor from service for an indeterminate period of time may place a severe firancial hardship upon an electric utility. The financial impact of the TMI-II accident upon the 
owners of that facility was exascerbated by the fact that the Pennsylvania Public Utility Commission was considering revocation of the certificate of public convenience for Metropolitan Edison, the operator and major owner of the facility, and did not for a substantial period of time allow that utility to recover the cost or replacement power occasioned by the shutdown of both TMI-I and TMI-II. (Although TMI-I was not implicated in the TMI-II accident, the accident to TMI-II and the public concern it generated led the NRC to suspend the operating license for TMI-I. Thus, both reactors were taken out of service for rate base purposes.) The experience of TMI is illustrative of the impact of NRC regulatory measures upon the decisions of a state utility commission. Such actions by the NRC can threaten the survival of the utility and affect the rates it charges. Thus, the TMI accident has implications for decision-making processes beyond those associated with the overriding concerns of health and safety. The Federal Regulatory response to TMI impinged upon the state economic regulatory process with consequent adverse financial impact upon the General Public Utilities (GPU) system of which Metropolitan Edison is a part. Thus, not only is it important for the sake of public health and safety that a regulatory regime have practices and procedures that can respond effectively and expeditiously to reactor accidents, but such capability is also necessary to mitigate the adverse financial impact of reactor accidents upon the utility. 


\section{Environmental Regulation}

\section{a. Siting}

For all practical purposes, the siting of generating facilities is no longer primarily a state or local land use decision. It has, in reality, become a federal responsibility. With regard to non-federal hydroelectric generating facilities, this has been the case since the Federal water Power Act of 1920 . As to the siting of fossil-fuel power plants, the provisions of the Clean Air Act have effectively superseded state and local land use regulations that previously determined the siting of such facilities. As for fission reactors, state and local siting requirements that conflict with those of the NRC are pre-empted and may not be enforced against the utility. Thus, given the general tendency of federal regulation to preempt the siting of new generating facilities, any regulatory regime applicable to fusion reactors is likely to continue this trend.

Although the siting of power plants may have effectively become a federal, rather than state or local, responsibility, there are aspects of power plant sitings that remain a matter of state responsibility: State laws generally delegate to publlc.utilities the right to acquire land by emminent domain. This typically requires a utility first to apply to the commission of the state in which the right is to be exercised for a certificate of public convenience authorizing the acquisition of land by emminent domain. Any party seeking to prevent the utility from exercising the right, 
if that party has the requisite standing must be afforded an opportunity to have their claim adjudicated. If the particular state law authorizes an adjudicatory hearing on the issue before the state commission, an aggrieved party must pursue their remedy before that forum since that is the exclusive procedure by which such a challenge can be made. After the grant of the power to take property by eminent domain, there is a separate legal proceeding to determine the value of the property to be taken. In this second proceedings, the proprietary of the grant to the utility of the right of emminent domain may not be challenged. In addition to the acquisition of land by emminent domain, state law generally requires a utility to obtain a certificate. of public convenience before a utility may acquire or construct facilities to be used in the performance of the utility's service. To the extent that this is a requirement of state law, the application for the certificate of public convenience may be challenged by a party with standing. If there is such a challenge, adjudicatory proceedings are usually initiated by the utility commission in question. In such a proceeding, the commission makes a decision whether to grant application on the basis of evidence submitted at the hearing. Issues regarding environmental protection, matters of public health and safety, and questions relating to the need for the proposed facility may be raised in such proceedings. 
b. Environmental and Health Standards

All fossil-fueled generating facilities are required to comply with state and federal environmental laws regarding the emission of pollutants into the ambient air and discharge of effluents into surface waters. Fission reactors, insofar as emissions and discharges of radioactive materials are concerned, are within the exclusive jurisdiction of the NRC, and are not subject to state regulation in this regard. This has been established authoritatively by the Supreme Court in Northern States Power Co. V. Minnesota, 405 U.S. 1035 (1972). The NRC also has exclusive jurisdiction over the discharge of radioactive material into navigable waters from fission reactors. Crane v. Colorado Public Interest Research Group, Inc., U.S. (1976). Prior to the enactment of NEPA, however, the AEC had always asserted that it had no jurisdiction over non-radioactive discharges from fission reactors. It was upheld in this position in state of New Hampshire vs. Atomic Energy Commission, et al, 406 F.2d 170 (1969), cert. denied, 395 U.S. 962 (1969).

State of New Hampshire involved the question of whether the $A E C$, in grating a provisional construction permit, should consider the deleterious effects of thermal pollution upon the Connecticut River in its decision making process. The state sought to challenge the decision of the AEC to ignore the effects of thermal pollution as outside its regulatory jurisdiction. With the advent of NEPA, however, the AEC could no longer disregard environmental problems 
of a non-radiological nature in its application review procedures, Calvert Cliff's Coordinating Committee, et al, 449 F.2d 1109 (1971). Viewing Calvert Cliff's and State of New Hampshire together, it is possible to conclude that the NRC must take into consideration non-radiological pollution problems in its application granting process. Thus, given the precedent of Northern States Power Co., it may be inferred that the Nuclear Regulatory Commission pre-empts state environmental laws insofar as they apply to nuclear fission reactors.

Fossil-fueled generating facilities are subject to state environmental protection laws, the provisions of the Federal Clean Air Act, and the Federal Water Pollution Control Act. These federal statutes, while purporting to defer to and recognize the primary interest of states in controlling their pollution problems, actually establish regulatory structures that formally confer upon EPA substantial authority in areas once considered mostly within the proyince of the states. A consideration of the provisions of the Clean Air Act (CAA) and the Federal Water Pollution Control Act (FWPCA) will reveal how a consciously articulated multi-layered federal approach is intended to work.

3. The Federal Clean Air Act

The Federal Clean Air Act authorizes the Administrator of EPA to set nationally uniform primary and secondary ambient air quality standards. These standards are based upon studies that purportedly establish a cause and effect relationship between 
quantities of given pollutants and their effects upon human health and welfare. Upon the promulgation of the national ambient air quality standards, each state is required to submit to the EPA Administrator a state implementation plan (SIP). To be approved, the SIP must comply with the provisions of section 110 of the Clean Air Act. This section requires that the state SIP provide for the attainment of primary ambient air quality standards within 3 years and the attainment of the secondary standards within a "reasonable" time. The implementation plans may be revised periodically on the initiative of either the state or the EPA Administrator. Although the original Clean Air Act of 1970 provided that the Administrator may require revision of the state plan only if it was inadequate to meet national ambient air quality standards, the 1977 amendments to the Act now authorize the EPA Administrator to force revisions of a SIP if it does not comply with the statutes' non-attainment provisions or the provisions regarding the prevention cf significant deterioration (PSD). The 1977 amendments also provide for an emission offset policy as part of the non-attainment program. Under this policy, a new stationary source seeking to enter an area in which the ambient air quality standards are exceeded must either obtain a commitment from other firms in the area to reduce their emissions by an amount greater than the level of emissions expected from the new source or the firm seeking to enter the area must similarly reduce its emissions from some of its local facilities. 
To remove any uncertainty on the subject, the 1.977 amendments to the Clean Air Act specifically establish a non degradation program. The amendments establish three categories for the classification of areas which have air quality cleaner than that required by the national ambient standards. The amount of pollution permitted in these legislatively established area classifications varies inversely to the classification. Thus, the least increment of pollution is permitted in a class I area.

Section 172 of the Clean Air Act requires states to revise their SIPs for regions which exceed national ambient air quality standards by July 1979 so that all national standards are attained by 1982 . With regard to pollutants from automotive emissions, hydrocarbons (HC) and nitrogen oxides (NOx), the 1977 amendments extended the time for compliance with national ambient air cuality standards to 1987. To the extent that national ambient air quality standards regarding hydrocarbons and nitrogen oxides are not met, on account of automotive emissions, there is an indirect effect under the clean Air Act upon stationary source emissions. If $\mathrm{HC}$ and NOx standards cannot be met through the control of automotive emissions, the introduction of new stationary sources within the area is governed by the non-attainment provisions insofar as these pollutants are concerned. Thus, the development of industries which emit hydrocarbons or nitrogen oxides may be inhibited for reasons unrelated to industrial-type pollution.

Section 173 of the Clean Air Act permits new major stationary sources to be located in non-attainment regions only if the 
following conditions are met: (1) the SIP has been revised to satisfy the requirements of the non-attainment programs; (2) emissions from the new stationary source, when considered with emissions from existing sources, will be sufficiently less than the total emissions from the existing sources permitted under the revised SIP so as to constitute "reasonable further progress toward attainment of ambient air quality standards"; (3) the new facility complies with the lowest achievable emission rate, defined in the Act as the most stringent emission limitation for a source of the type proposed that is contained in any SIP or achieved by any source of the same type in actual operation; (4) the owner or operator of the proposed source is able to show that all major stationary sources witin the same state owned, operated, or controlled by such person are in compliance with all applicable requirements of the Clean Air Act.

The non-attainment and PSD programs are pollutant specific. Thus, it is possible that the same area may, with regard to one pollutant, be a non-attainment area, while with regard to another pollutant, it may be subject to the provisions of the Act relating to the prevention of significant deterioration. Depending upon circumstances, it is possible for an area with air quality better than that required by applicable national ambient air quality standards to become a region in which the standards are exceeded. In that event, the provisions of the Act relating to non-attainment areas come into operation rather than those applicable to PSD areas. 
4. The Federal Water Pollution Control Act

The Federal Water Pollution Control Act (FWPCA) represents a multi-layered federal approach significantly different from that embodied in the clean Air Act. The major difference in concept between the FWPCA and the Clean Air Act is that the FWPCA requires a federal permit system for the discharge of pollutants into the surface waters of the United States. This permit system is a fundamental part of the legislation, creating a national pollution discharge elimination system (NPDES). Permits issued under the Act are referred to as NPDES permits. The permit requirements of the Act (Section 402) are applicable both to existing and new sources.

Under the FWPCA, the EPA may delegate to a state the authority to issue section 402 permits, but EPA retains authority to veto the issuance of any given permit a state issues pursuant to its delegated authority and, in certain circumstances, EPA can reassume the entire 402 program.

Whenever a federal license or permit is necessary to engage in any activity, the FWPCA (Section 401 ) requires that the state certify to the federal licensing or permitting agency that the facility in question meets the discharge requirements of sections $301,302,303,306$ and 307 of the Act. Such a certification is a condition precedent to the issuance of the federal license or permit. The certification may include such state imposed conditions as are necessary to ensure compliance with state water pollution 
control regulations. These additional conditions are then incorporated into the federal license or permit. Thus, all NPDES permits issued under section 402 of the FWPCA are required to incorporate such state conditions as are contained in the state certification under Section 401 of the Act.

Sections 301 and 304 of FWPCA establish a federal effluent limitation program for existing pollution sources. For conventional pollutants, essentially organic compounds that over time decompose into harmless components, effluent limitations reflecting the "best conventional pollution control technology" are required. For non-conventional pollutants, emission limitations are based upon the stricter "best available control technology standard." With regard to sources discharging toxic pollutants, Section 301 of the Act requires effluent limitations based upon the best available control technology. The thermal component of any discharge is specifically made subject to the requirements of best available control technology under section 304 of the FiNPCA.

Section 306 of the FWPCA places more stringent controls than those in section 301 upon new point sources of pollution and old sources that are modified in such a manner as to emit more or different pollutants than before. Sources subject to this section must institute pollution controls that reflect the application of the best available demonstrated control technology, processes, operating methods or other alternatives, including where practicable, a standard permitting no discharge of pollutants. If a "modification" within the meaning of the Act is made to an existing 
source the entire plant must then comply with section 306 new source limitations or be forced out of business. Once brought into compliance with section 306 of the Act, a source may not be required to add any new pollution control equipment for either a ten-year period, that begins with the completion of construction, or until the expiration of the tax depreciation period for the facility, whichever first occurs. Since the period of tax depreciation depends upon the method of depreciation selected this provision would only be of substantial benefit if the method of depreciation chosen permits the amortization of the plant over more than ten years. The Federal Clean Air Act contains no such provision.

Since state certification is required as a condition precedent to the issuance of a federal permit or license under section 401 of the FWPCA, the question may arise as to whether state certification for the thermal discharge from a fission reactor is required prior to the issuance of an NRC construction permit. Under the rationale of Northern States Power Co. and that of Calvert Cliff's, it would appear that the certification provisions of the FWPCA may not apply to facilities for which an NRC construction permit is required. Thus, a state would not be able to impose state standards for thermal pollution upon the permitees or licensees of the NRC. However, the degree of uncertainty that pervades this question deserves recognition in any legislation establishing a regulatory structure for fusion reactors. 
5. The Realities of Uniform Federal Standards

One of the primary objectives of both the Federal clean

Air A.ct and the FWPCA is to prevent industries from "bargain

hunting" for states with the least costly environmental regulatory regimes. The setting of national effluent standards under the FWPCA and the establishment of national ambient air quality standards under the Clean Air Act are a response to this problem. However, as the current controversy between Pennsylvania, Ohio, and the EPA regarding both water and air standards demonstrates, this objective may not be fully achieved. In regard to that controversy, it is important to note that EPA carries out its responsibilities under these statutes through its regional offices. The Philadelphia regional office of the EPA is responsible for ensuring state and industry compliance with water and air standards in Pennsylvania. The Chicago regional office of EPA is responsible for compliance on the part of the state of ohio and industries therein. The perceptions of the Chicago regional office of EPA and the Philadelphia regional office of that agency may differ with regard to the same standards. That regional offices of a federal agency may differ with regard to the "interpretation" of the same standards or regulations should be of no surprise to anyone. However, it is of no little consequence that one of the more important objectives of both the federal acts may be undermined, not by the states as anticipated, but by regional offices of the same federal agency.

B. The Appropriateness of a Multi-Layered Federal Approach as a Model for a Fusion Reactor Regulatory Structure The multi-layered approach in the field of federal 
air and water pollution control legislation is the product of modern technology creating adverse health and welfare impacts in areas that traditionally were considered matters of state concern. To chronicle the step-by-step intrusions by the federal government into the control of air and water pollution is to recount the gradually diminishing reluctance of congress to address the serious environmental problems created by modern technology which cannot be effectively controlled by the states themselves. The multi-layered federal approach to environmental problems, therefore, is a response to perceived constitutional limitations and political realities. These perceptions, however, underwent significant change in the $1960 \mathrm{~s}$ and $70 \mathrm{~s}$ with regard to environmental matters. Thus, in response to increased public awareness of environmental degradation, NEPA was enacted in 1970 and soon after other strong federal initiatives in the pollution control field became law.

While these laws impose federal standards upon the states, they can not work effectively without active state cooperation since federal enforcement capability in the environmental field is extremely limited. Witness, for example, the enforcement of the Occupational Health and Safety Act (OSHA) in those cases where the state chooses not to have OSHA responsibilities delegated to it. Thus, the primary requisite for the enforcement of federal air and water pollution control regulations is sympathetic state cooperation.

Both the Federal Clean Air Act and the FWPCA have spawned litigation on both the federal and state level challenging, on 
various grounds, the legal validity of the regulatory format. When an approved SIP, which contains components of state law and regulation, is deemed to be enforceable both by the federal and state legal and administrative processes, it is not necessary to carry speculation far to discover many grounds for legal challenge. (1) Moreover, although both the clean Air Act and the FWPCA permit citizen suits to be brought in federal courts to seek compliance with federal standards, the bringing of such suits places the responsible agency in a defensive posture. There is an inherent complexity, at least in the field of water and air pollution control, to the multi-layered federal approach. This complexity arises not only from the necessary interaction between different levels of government, but also from the technical difficulty of pollution control. To be fair, a multi-layered approach may have a theoretically high degree of responsiveness to regional concerns because of the involvement of state and local governmental agencies. However, despite the advantages to approaches of this sort in the field of environmental protection, there are serious shortcomings to such a system as a model for a regulatory structure for fusion reactors.

The regulation of fusion reactors for the generation of electrical energy present a qualitatively different set of policy and administrative problems than does the control of air and water follution. The need for a concentration of expertise first to develop suitable rules for the design of fusion reactors and then

(1) Eg. whether state regulation included in an approved SIP may be challenged through state administrative and judicial proceedings or whether approval makes them immune from state review. 
to review applications for construction permits, argues in favor of a dedicated federal agency. Such an agency is better able consistently to apply regulatory criteria to a special area of concern that is sharply defined both in terms of the number of facilities regulated and the type of facility to be regulated. In the field of air and water pollution control, on the other hand, the number of emissions sources is legion and the variety of pollutants they discharge is also extremely varied. The geographic dispersion of pollution sources throughout the country and the differing environmental, economic, and political contexts in which they must operate preclude a dedicated single federal agency approach to pollution control problems. Politically, if for no other reason, a multi-layered federal approach, assuming a federal presence at all, is necessary. Conversely, a dedicated single federal agency approach for the permitting and regulation of commercial fusion reactors is better adapted to the problems of such reactors than is a multi-layered federal approach. A single, dedicated federal agency with expertise in fusion reactor technology is in a much better position to formulate design criteria and develop appropriate health and safety standards than could be done by $\bar{c}$. multi-layered federal program. Furthermore, the multilayered federal approach by its very nature has built in impediments to standardized decision-making that is required in the case of fusion reactors.

Considering the delay in the licensing and permitting of fission reactors that now exists in a dedicated, single federal agency such as the NRC, a multi-layered federal approach can only further extend an already unacceptable regulatory lag. Taking as a model the 
permit procedures that may be delegated to states under section 402 of the FWPCA, it is clear that such a system has the inherent potential for prolonging the regulatory process beyond what is necessary to arrive at a sound decision with respect to the licensing of a fusion reactor.

1. Delegation of Inspection and Enforcement to the States However, there is one exception to the above statements on multi-layered regulatory models that is worthy of consideration. Federal agencies generally do not have sufficient resources or inclination to enforce their rules and regulations over a wide geographical area. It may be feasible, therefore, in a regulatory structure for fusion reactors to provide for the delegation to state agencies under appropriate conditions of the authority to monitor and enforce federal regulations for fusion reactors. Such a limited delegation of authority to state agencies with the technical capability to enforce the appropriate regulations has the advantage of providing a degree of state participation in the regulatory process that could enhance state and local acceptance of fusion technology. It could also result in more effective monitoring of the operations of such reactors than otherwise would be the case.

Such a delegation, as proposed herein, presupposes: (1) the legislative authority for the delegation; (2) the capability and willingness on the part of the states to carry out an inspection and enforcement program on behalf of the federal agency; (3) financial support from the federal government to states willing to accept such delegation; (4) a system of effective reporting to the federal agency; and (5) programs of education and training for state personnel to enable them competently to carry out 
their delegated duties. The delegation of inspection and enforcement responsibilities herein contemplated would not prevent the federal agency from maintaining its own enforcement arm, but would enable it to delegate enforcement duties to states willing and able to accept them. Except for this limited purpose, however, any agency regulating fusion reactors must, of necessity, be a single federal agency having comprehensive and exclusive jurisdiction over the regulation of fusion reactors.

C. Regulation by an Independent Regulatory Commission versus an Executive Agency for the Case of a Dedicated Regulatory Entity

The federal independent regulatory commissions have come under critical study by scholars in political science and public administration, by a variety of governmental study commissions, and by congressional committees studying governmental organization and re-organization. The most frequent criticisms of independent regulatory commissions are: (I) they are not directly responsible in a meaningful manner to either the executive or legislative branch of government (although this may also be a desirable attribute from the point of view of long-range policy development); (2) they cannot effectively delegate routine administrative responsibilities on a rational basis; (3) independent regulatory commissions are frequently unable to engage in the planning activities necessary to develop long range goals and objectives to implement their legislative authorization, since they tend to be constrained by ex parte rules designed to assure their objectivity in adjudicatory hearings on which they may be required to rule; (4) such commissions tend to be 
more solicitious of the industries they regulate than the interests of the public in general; (5) they tend to forumlate policy through adjudicatory processes rather than through rule-making; and (6) their enforcement capability is severely limited by diffuse authority associated with collegial management as well as by budget constraints, lack of sufficient enforcement staff, a lack of interest in enforcement activities and the limited effectiveness of the enforcement processes available to them under their authorizing legislation.

The members of the independent regulatory commissions on the federal level are appointed by the President with the advice and consent of the Senate for a term of years specified in the legislation creating the particular agency. The members initially appointed to the commission serve staggered terms so that the terms of the entire membership never expire at the same time. The President appoints the chairman of an independent regulatory commission with the advice and consent of the Senate. Since the Supreme court does not recognize these commissions as within the Executive Branch of government, the President does not have unlimited powers to remove the members of such agencies. Humphrey's Executor vS.U.S., 295 U.S. 602 (1935); Wiener VS. U.S., 357 U.S. $349(1958)$.

The manner in which members of independent regulatory commissions are appointed effectively isolates them from direct executive control, and at the same time, only permits the senate to veto the appointment of any single member when a vacancy occurs. Except with the creation of a new independent regulatory agency, moreover, 
one President is unlikely to have an opportunity to name all the members of a given commission. Thus, the independent regulatory commissions have a high degree of autonomy and are not directly responsible either to the President or congress. It is only when such an agency takes a controversial position or the president seeks to appoint a person to the agency who is opposed by significant political interests that an independent regulatory commission will undergo serious congressional scrutiny. The recent efforts of the Federal Trade Commission to adopt a more consumer oriented policy in the face of substantial business opposition is but one example of the type of situation where congressional power is likely to be exerted vis-a-vis such agencies. However, since independent regulatory agencies, on the whole do not tend to take agressive action, congressional intervention into their activities will likely be episodic in nature. The net result is that the operations of such agencies undergo little effective supervision.

Due to the lack of effective oversight and a desire to preserve the status quo, the independent regulatory agencies have very little incentive to make long-range plans within the scope of their delegated authority. This has the effect of inhibiting the conscious formulation of policy, except perhaps, on a case-by-case basis. Generally, independent regulatory bodies will not, apart from a given discreet matter before them, attempt to deal with broad issues within the domain of the agency. This lack of interest in planning and making broad policy determinations is a result of the way in which these bodies are selected, the varied views of the members of the body, and a bureaucractic disposition not to "rock the boat." 
Unless Congress unambiguously confers upon the chairman or an executive director of a regulatory commission the authority to administer the routine affairs of that agency, the day to day administration of the organization must be undertaken by the commission in a collegial fashion. This tends to undermine good administrative practice, especially if each commission member has equal authority with the others, to determine the internal workings of the agency. Personnel actions, for example, of the most routine nature may be part of the agenda of a public meeting of the body. The lack of centralized control increases tendencies within the agency's staff to ignore lines of authority and promotes inefficiency by occupying the commissioners with such things as budgetary, procurement and personnel matters when their attention could be more profitably employed in formulating basic policy for the agency.

Independent regulatory bodies are likely to become more sensitive to the needs of the particular branch of the economy they regulate rather than the public interest thet purportedly gave rise to the need for the regulation. The regulated groups give sustained attention to the activities of the agencies regulating them. They are in a position to command the necessary resources to persuade the regulatory body to take a specific course of action in a certain matter. To accomplish this, they garner arguments and factual material to support their viewpoint before the agency. Often, industry groups are from time to time solicited by the agency for their views on proposed regulations. This concentrated preoccupation on the part of a regulated 
industry with the activities of the regulators sharply contrasts with the negligible interest in the regulatory process expressed by the general public.

There are several reasons for the lack of effective public participation in the regulatory process. First, the generai public has a variety of interests and is unlikely to coalesce around the workings of a particular regulatory agency. Second, the economic disparity between the regulated group and the average member of the public who may wish to participate in regulatory processes and determinations are such as to preclude that person from having a meaningful impact upon the agency. In addition, regulatory agencies generally have not been known for their assiduous interest in providing the public at large with knowledge of their internal procedures and the mechanisms by which individuals may intervene in agency proceedings. On the contrary, participation often requires adherence to strict agency procedures that greatly inhibit unskilled intervenors. These factors tend to promote regulatory agency conduct that is "friendly" to the industries they regulate.

The appointment process enables organized interest groups to express their views during confirmation hearings in the Senate with regard to the person to be appointed or reappointed. If an appointee is perceived as adverse to the interests of the regulated group, an intensive lobbying effort is likely to occur against his or her appointment. Frequently such opposition will result in a decision by the senate to reject the appointment. Finally, a commissioner may be chosen because of their general disposition in favor of the regulated industries. The process of 
appointment is such, and the interest of the regulated group is such, that by the natural operation of the political process there is a strong likelihood that appointees to regulatory bodies will be, to a great extent, surrogates for the industries they purportedly are authorized to regulate. 
III. THE NUCLEAR REGULATORY COMMISSION

A. History of the NRC

NRC assumed the regulatory responsibilities of the AEC with the enactment of the Energy Reorganization Act of 1974. This Act was the outgrowth of a perceived public demand to separate the promotional and developmental activities of the AEC from the licensing and regulatory functions of the agency. To understand the current structure and processes of the NRC, it first is necessary to review the history of the AEC and the various amendments to the Atomic Energy Act which preceded the abolition of that agency.

The original Atomic Energy Act of 1946 created a fivemember civilian Atomic Energy Commission, appointed by the President with the advice and consent of the senate. This Act conferred upon the AEC a virtual monopoly over nuclear technology and transferred to it all nuclear related programs of the military. The intent of the Act was to strengthen government control over nuclear weapons and to safeguard the then existing monopoly of the United States over these weapons. Except for some concern expressed in the Act that fissionable material could be diverted, the original 1946 Act did not contain provisions relating to public health and safety.

In the early 1950s, officials in the government realized that there was potential for peaceful uses of atomic energy. In 1952, the chairman of the AEC proposed that Congress make the development of nuclear power a top governmental priority. Later 
- that year, President Eisenhower delivered his famous "Atoms for Peace Address" to the United Nations. Subsequently, the President, the AEC, the Joint Congressional Committee on Atomic Energy, and the industrial community joined forces to promote legislation to facilitate the development of nuclear power by private enterprise. Congress responded by the enactment of the Atomic Energy Act of 1954 (P.L. 84-703). Section 3(d) of that Act stated that one of the purposes of the statute was to encourage widespread participation in the development and utilization of atomic energy for peaceful purposes "to the maximum extent consistent with the common defense and security and with the health and safety of the public."

The Act provided for the private ownership of nuclear facilities, the private use of fissionable materials, and private access to technical information in the hands of the government. The Act also established a two-phased procedure for the ultimate licensing of nuclear reactors which required a utility to obtain both a construction permit and an operating license from the Commission in order to operate an atomic reactor. This dual procedure is still a part of the licensing process as administered by the NRC. The Act conferred upon the AEC authority to adopt regulations, standards, and orders to effectuate the purposes of the statute. It also provided for an administrative hearing upon the request of any person whose interests might be affected by a proposed nuclear facility, and defined the procedures for obtaining judicial review of final orders issued by the AEC. 
In 1957, the Act was amended to establish the Advisory Committee on Reactor Safeguards (ACRS), a statutory body to review and prepare a public report on the safety aspects of all applications for construction and operation of nuclear facilities. Previous to 1957, the ACRS was administratively established by the merger of a reactor safeguard committee and an industrial committee on reactor location problems. The 1957 legislation also required the AEC to hold public hearings on all applications for permits or licenses.

In 1958, the Office of the Hearing Examiner was established. The hearing examiner took evidence regarding applications for construction permits and operating licenses and then recommended a decision to the commission on the basis of the record established at the hearing. The AEC would act upon the recommendations of the hearing examiner and either afirm, modify, remand, or reverse them.

The AEC established the Atomic Safety and Iicensing Boards (ASLB) to replace the hearing examiner system pursuant to amendatory legislation in 1962. These boards consisted of three members, one trained in the law and the two others technically trained. In 1969, the AEC created the Atomic Safety and Iicensing Appeal Board (ASLAB). Decisions of ASIB under the 1969 amendments could be appealed to the ASLAB. The action of the ASLAB was reviewable by the AEC itself. The AEC, however, could refuse 
to review the decision of $A S I A B$. If the AEC did so the decision of ASLAB constituted a final order and judicial review of that action could be obtained.

Under the Energy Reorganization Act of 1974, the NRC essentially maintained the same administrative structure for licensing and regulatory functions as the Atomic Energy Commission had. The 1974 Act retained the ASIB and ASLAB as the adjudicatory arm of the NRC. The Energy Reorganization Act also retained the ACRS as part of the application review process. By way of change, the 1974 amendments altered the prior regulatory structure by creating the position of Executive Director for Operations (EDO) and the following program offices: (1) Office of Nuclear Reactor Regulation (NRR); (2) Office of Nuclear Material Safety and Safeguards (NMSS); (3) Office of Regulatory Research (RES). In addition to these statutorily created offices, the NRC administratively established the offices of Standards Development (SD) and Inspection and Enforcement (I\&E).

B. Scope of Authority and Internal Organization of the NRC The NRC has overall responsibility for the operation of the agency, as is common among federal independent regulatory commissions. It exercises quasi-judicial, policy-making, and executive functions. The NRC exercises all these functions in a collegial manner. The chairman of the NRC regards himself as the "first among equals" rather than the executive head of the agency. 
The commission appoints the EDO, who serves at its pleasure, to supervise the conduct of the commission's day-to-day operational and administrative activities. Although the EDO is responsible for the smooth functioning of the NRC's activities, the directors of certain offices are authorized by statute to communicate with and directly report to the commissioners. The director of NRR, for example, is expressly authorized by section 203 of the Act to report directly to the commissioners. The Act, however, was amended in 1978 to require that the directors who communicate directly with the commissioners, must inform the EDO of such communications.

The NRR reviews the location of commercial, test, and research reactors prior to issuance of construction permits and operating licenses. In its review of construction permit applications, NRR examines the applicant's preliminary safety analysis report (PSAR) and its environmental report, both of which must accompany and be part of the application. It also reviews the financial capability of an applicant to ascertain whether it is properly indemnified against accidents and is not in violation of anti-trust laws.

NMSS is responsible for protecting public health and safety, environmental values, and national security in the licensing and regulation of nuclear facilities and materials. It reviews and assesses safeguards against potential threats, thefts, and sabotage. 
RES implements research programs to assist the NRC in the performance of its regulatory functions.

I\&E has the responsibility of inspecting licensees to ensure that the construction and operation of their facilities comply with commission regulations and license provisions. It is also required to identify conditions that may adversely affect the protection of nuclear materials and facilities, the environment, or the health and safety of the public. The office inspects applicants and their facilities to provide a basis for recommending either issuance or denial of licenses. It investigates accidents, incidents and allegations of improper action that involve nuclear material and facilities.

SD develops regulations, guides, and standards needed for the regulation of facilities and materials that threaten the public health or the environment. It also coordinates NRC participation in national and international activities relating to standards setting.

\section{NRC Licensing Procedures}

Regulations have been promulgated under the Atomic Energy Act of 1954 setting standards for radioactive emissions (10 C.F.R. 20), general design criteria for nuclear power plants (10 C.F.R. 50, appendix A), and regulations establishing the duties of those handling nuclear materials to protect the public and the environment. The regulations provide that no permit or license will be issued unless the commission is reasonably assured that the health and safety of the public will not be endangered 
C.F.R. Section $50.40(a))$.

Prior to tendering an application for a construction permit, the utility, in an informal manner, usually informs commission staff of the basic features of the reactor plan and undertakes to discuss review "philosophy." The NRC staff and the applicant may reach an informal understanding as to siting, general design, and applicable license requirements. These discussions take place prior to the formal docketing of the construction permit application and occur outside of public view.

Once the utility considers an application for a construction permit to be acceptable, it formally files its application accompanied by a fee of $\$ 125,000$. If after an "acceptance review" by the NRC staff, the application is accepted, it is docketed and public notice of the filing is published in the Federal Register. Copies of the application are provided to appropriate state and local officials and are also placed in a public reading room in Washington, D.C.

The application for the construction permit is required to include the applicant's PSAR and environmental report, both of which become the object of NRR review. The requirements for the PSAR are set forth in 10 C.F.R. Sections 15.34 and 15.34 (a). The essence of these requirements is stated in the report of the Office of Chief Counsel to the President's Commission on the Accident at Three Mile Island (pages 39-40).

The environmental data accompanying the application for a construction permit must contain a description of the area to be 
affected by the proposed nuclear reactor. It must also include consideration of those factors that are required to enable the NRC to prepare a draft and final Environmental Impact statement (EIS) that complies with the requirements of NEPA. (10 C.F.R. Section 5120).

1. NRC Compliance with NEPA

The NRC staff reviews the environmental report of the utility in order to prepare a draft EIS. The draft EIS must contain a preliminary cost benefit analysis that considers the adverse effects of the reactor, the economic benefits of the proposed reactor, and available alternatives to the facility that could reduce or avoid adverse environmental impacts. Such alternatives include other locations for the proposed facility, different means of generating the power, and the alternative of not constructing any facility. The draft EIS must consider the proposed reactor and the alternatives to it in light of the standards imposed by other agencies. It must also evaluate the potential radiological impact of the reactor, even though the proposal meets the requirements of commission regulations authorized by the Atomic Energy Act of 1954 .

The draft statement will normally include a preliminary conclusion by the staff as to whether, after considering the cost benefit analysis, the requested permit should be granted, denied, or issued with conditions. Under appropriate circumstances, the preliminary conclusion in the draft statement might indicate that two or more alternatives are under consideration. 
After the draft EIS is circulated and commented upon by other federal agencies and groups in conformity with CEQ regulations, the NRC staff prepares the final EIS. The final statement considers the same matters that were considered in the draft EIS. The final statement must make meaningful reference to any responsible view opposing the staff's position that is not adequately discussed in the draft statement. All substantive comments or summaries thereof received on the draft statement must be included in the final statement, regardless of whether they are discussed in the text of the statement. As a matter of practice, the commission's final EIS contains a section devoted to the consideration of specific comments addressed to the draft statement.

The final EIs must include a cost benefit analysis and a decision by the staff recommending what action the commission should take. The final EIS, draft statement, and any comments must accompany the application for the construction permit. These form a part of the construction permit application and are given consideration in the application review process.

\section{NRC Hearing Procedures}

The application process then involves a hearing before the ASIB, in which the applicant, NRC staff, and any intervenors are formal parties with full rights to participate in the hearing process. Much of the direct testimony of the applicant and staff is in prepared written form. Witnesses, whose testimony is taken during the hearing process, are sworn and subject to cross 
examination by other parties to the proceeding. In addition to testimonial evidence, documentary evidence may be received during the hearing process. When necessary compulsory process ${ }^{(1)}$ is available to the parties to compel the attendance of witnesses and the production of documents.

At the conclusion of the hearing, the ASLB renders its decision on the basis of the record before it. As stated above, any party to the proceeding may appeal the decision to the ASLAB, which may affirm, reverse, modify, or remand the decision of the ASLB. The decision of the ASLAB is based entirely upon a review of the record made before the ASLB and not upon additional evidence taken by the ASLAB.

E. Judicial Review of NRC Orders

Any party who is unsatisfied with the decision of the ASLAB may request review by the NRC. The NRC may either grant or deny the request for review. If the NRC declines review of the decision of the ASLAB, the decision of the ASLAB becomes, for purposes of judicial review, the final order of the NRC. Final orders of the NRC granting or denying licenses are reviewable by the Federal Court of Appeals for the circuit in which the petitioner resides or has its principal office, or can be brought in the District of Columbia circuit. A party unsatisfied with the decision of the Court of Appeals, may petition the Supreme Court to review the decision. The Supreme Court may, in its discretion,

(1) The right to subpoena 
choose to review the case.

Under principles of administrative law, formulated by judicial decision and enacted into statute, courts ordinarily will only review those administrative agency decisions that are final in nature. In the absence of specific statutory authority, the courts will not interfere with the decision-making process of the agency at an interim or interlocutory ${ }^{(1)}$ stage. Furthermore, if a party to an administrative proceeding fails to follow the procedures applicable to the administrative review process, the courts will not review agency final orders at the instance of such party for the reason that statutory remedies must be strictly pursued. Thus, judicial review of a final order of the NRC is only available to the parties who exhaust all administrative remedies embodied in the Atomic Energy Law of 1954 as modified by the provisions of the Energy Reorganization Act of 1974. Therefore the failure to take a timely appeal to the ASLAB from a decision of the ASLB will preclude a party from obtaining judicial review of the decision.

F. Limited Work Authorizations

Although it might be inferred from the foregoing that construction cannot proceed before the issuance of a construction permit, after the exhaustion of the entire administrative review process, the NRC may, nevertheless, grant a "limited work

(1) An interlocutory order is one made during the course of a proceeding that does not make a final disposition of a party's claim. 
authorization" (LWA). Such an authorization may be granted after the staff review and the ASLE hearing on plant siting and environmental impact. The IWA allows construction to proceed pending ongoing review of the construction permit application. The 1978 NRC Annual Report notes that the practice of granting an IWA has served to shorten the construction and licensing process by as much as seven months.

G. Critiques of the NRC

Even before the accident at Three Mile Island, the NRC and its predecessor, the AEC, have been the subject of substantial criticism from numerous sources. Although the growth and influence of the environmental movement in the $1960 \mathrm{~s}$ and $1970 \mathrm{~s}$ gave substantial impetus to the examination of the operations of the AEC and the NRC, the accident at Three Mile Island provoked intensified interest in the operations of the NRC. Scrutiny of these bodies by scholarly and other sources revealed that both the NRC and its predecessor were plagued with those endemic ills that characterize the independent regulatory commissions generally. The Kemeny Commission and the report of its general counsel are replete with negative evaluations of the NRC that, while specific and peculiar to NRC operations, nevertheless add to the increasing body of literature critical of independent regulatory commissions as a whole.

The demise of the $A E C$, but twenty years after it had been authorized to license and regulate commercial nuclear reactors, was in large measure due to criticism that the AEC had two 
incompatible legal responsibilities: (1) the promotion and development of the peaceful uses of atomic energy; and (2) the licensing and regulation of atomic reactors in the interest of the public health and safety. However valid these criticisms may have been, they led to the passage of the Energy Reorganization Act of 1974, which abolished the AEC and conferred upon the newly created NRC those licensing and regulatory functions formerly performed by the Atomic Energy Commission.

As is typical with governmental reorganizations, the more things change, the more they remain the same. This proved true of the NRC, which in organizational structure and orientation differs little from its predecessor. Not only did the NRC inherit most of its personnel from the AEC but it also carried forward the same administrative structure and processes.

H. Public Perception of the Risks of Nuclear Power and its Regulators

After the accident at Three Mile Island the general public became sufficiently fearful of nuclear energy to be receptive to a slowdown in the development of this form of energy. (1) Despite the ever-rising price of oil and the increasing dissemination of information on the adverse environmental impacts of coal, the public was uneasy in its acceptance of nuclear power. Public

(1) A public opinion survey conducted by the Louis Harris Organization after the TMI II incident and reported in the June 9, 1980 edition of Atomic Energy Clearinghouse found that 578 of the general public favored a temporary ban on the licensing of new nuclear power plants. 
fear of a catastrophic accident at a power plant, concern over nuclear proliferation, fears regarding the health effects of low level radioactive releases, problems with the storage of long lived nuclear wastes, security problems perceived as inherent in the use of breeder reactors, and the realization that nuclear energy was not as inexpensive as many of its proponents indicated, all conspired to reduce public acceptance of nuclear energy. There are two major reasons why public perception of the risks of nuclear power is often at odds with many expert assessments of its dangers. The first reason involves the inherent inability of human beings to think rationally (i.e., to accurately evaluate the relationship between risks and benefits and to act in accordance with such a determination). Empirical research has demonstrated that a person's subjective evaluation of risk will nearly always vary from the objective probabilities. These studies have shown that our inability to think probabilistically deteriorates even further when certain conditions are present, that people will subjectively exaggerate the probability and severity of risks which:

1) are easily recalled or are easily remembered,

2) are certain to be fatal or have especially severe consequences, and

3) are likely to take many lives.

(1) Slovic, Paul; From Shakespeare to Simon: Speculations--And Some Evidence--About Man's Ability to Process Information; Research Monograph; Vol. 12, No. 12; April 1972 
Since all of these conditions are present in the case of a catastrophic nuclear accident, the general public's assessment of the risks attendant to the operation of an atomic power plant will diverge from the objective probabilities for such an occurrence.

The second major reason for the divergence of lay and expert opinion as to the dangers of nuclear reactors involves the general public's perception of the benefits and adverse consequences of atomic power plants. As already mentioned, humans are unable to objectively evaluate probabilities and also exaggerate the likelihood of high risk (or high benefit) events. The problem for those wishing to develop nuclear power is that the general public, by and large, does not value very highly the benefits of nuclear energy and greatly fears its adverse consequences. A study conducted in 1978 showed that the general public viewed nuclear power as a supplement to existing sources of electricity which themselves were viewed as adequate. (I) In contrast, the risks of nuclear power are seen to be particularly severe. They are considered involuntary, unfamiliar, potentially catastrophic, likely to be fatal, and dreadful (i.e., carcinogenic, lingering, and mutagenic).

Perhaps the most important reason for the public's fear of

(1) Slovic, Lichenstein, Fischhoff, Images of Disaster; Perceptions and Acceptance of Risks from Nuclear Power; In press in G. Goodman (Ed.) Impacts and Risks of Energy strategies: Their Analysis and Role in Management. New York: Academic Press, 1979. 
nuclear power is the association between reactors and atomic weaponry. This association finds expression in the frequently expressed fear that a power plant might "blow-up" like an atomic bomb, despite much public information describing the impossibility of such an event. In addition to the fear of catastrophic accidents, the noisy debate between government and utility experts on the one hand, and scientists opposed to nuclear power on the other, has heightened public concern over the safety of nuclear reactors. After the accident at Three Mile Island, public apprehension regarding nuclear energy reached its zenith. The responses to this accident on the part of the nuclear industry, government, and the mass media ${ }^{(1)}$ primarily served to increase public fear of nuclear energy and its distrust of those involved in its exploitation and regulation. The NRC and the utility involved in particular suffered a major loss of trust and confidence on the part of the public. (2)

I. The Kemeny Commission

The President's Commission on the accident at Three Mile Island (the Kemeny Commission) was charged with the task of making a comprehensive study and investigation of the accident. The charge included the task of evaluating the licensing, inspection, operation, and enforcement procedures of the NRC as they applied to the damaged reactor at Three Mile Island. The Kemeny Commission

\footnotetext{
(1) Report of The President's Commission on The Accident at Three Mile Island, Washington, D.C., Oct. 1979, pp. 35-38

(2) Id. at pp. 57 and 58
} 
made its report to the President on October 30,1979 . It made several findings critical of the NRC and it recommended the abolishment of the commission and the creation of a new agency within the Executive Branch of government to be headed by a single administrator. The administrator would be appointed by the President with the advice and consent of the Senate. The report also recommended that the substantive statutory mandate for the new agency be clarified so as to make its primary statutory mission the assurance of safety in the generation of nuclear power, and the protection of nuclear materials from theft, diversion or loss. With respect to rulemaking, the Kemeny Commission recommended essentially the same type of rulemaking process as is articulated in Executive Order 12044. The Kemeny Commission's recommendation on licensing procedures attempted to "foster early and meaningful resolution of safety issues before a major financial commitment in construction can occur." Although it would retain the two step application procedure, it recommended that the new agency be authorized to conduct a combined hearing on construction permits and operating licenses whenever plans can be made sufficiently complete at the construction permit stage. The Kemeny Commission contemplated a twotiered administrative adjudicatory process with a hearing board and an appeal board. The decision of the appeal board would constitute the final agency action for purposes of judicial review. There would be no review by the agency administrator under the recommendations of the Kemeny Commission. 
The overall recommendations with regard to the NRC, made by the Kemeny Commission, are based upon its findings. The findings may be summarized as follows:

(1) Primary emphasis of NRC is not given to overall safety issues, but to the licensing of reactors.

(2) Licensing and operation of nuclear reactors can take place without resolving generic safety problems.

(3) The NRC has no systematic method for evaluating the information it collects on the operation of plants or of identifying the danger signals of possible generic safety problems. This is so, although the General Accounting Office in 1978 criticized the agency for this failure.

(4) The commissioners have isolated themselves from the licensing process and from the overall management of the NRC. As far as the licensing process is concerned, the Kemeny Commission attributed this to unnecessarily stringent ex parte(1) rules.

(5) Major offices within the commission operate independently of each other. This is a common bureaucratic failing neither peculiar to the NRC nor independent regulatory bodies. However, such conditions may lead to confusion on the part of operators of nuclear reactors regarding the office of the commission responsible for a given problem.

(6) The permit and license application process allows huge economic investments on the part of utilities prior to the grant of either the construction permit or operating license. It is contended that the safety review may thus be influenced by financial considerations that lead to a reluctance to impose major changes at the operating license stage.

(7) Safety issues are inadequately treated in the licensing process.

(8) The Office of Inspection and Enforcement (I\&E) performed little independent testing of construction

(1) Communication made off the record by the decision-making authority with less than all parties to the proceeding. 
work and relied heavily on self-evaluations by the utility. It spent little time observing construction work and did not routinely communicate with those engaged in the actual construction. Inspectors perceived that commission procedures regarding their responsibility are unclear and lacking in sufficient technical guidance. I\&E makes little systematic review of and has no formal review mechanism for the evaluation of licensee event reports (IER), in which utilities report and evaluate important incidents. Thus it must rely on individuals to recall events and to identify generic conerns.

(9) Throughout NRC there is an absence of any overall systems to measure and improve the quality of safety regulations. The systems for management and internal quality assurance are inadequate. There is an absence of any systematic effort to obtain and utilize public health related research of other federal agencies, particularly the Department of Health and Human Services and EPA.

(10) Information and direction to licensees by the NRC was at times fragmented and misleading.

(11) The NRC is incapable of fulfilling its responsibility for providing an acceptable level of safety for nuclear power plants with its present organization, staff and attitude.

The findings and recommendations of the Kemeny Commission are based upon its general counsel's report on the NRC. The general counsel's report goes into detail regarding some fundamental deficiencies in the permitting and licensing process. It identifies maladapted processes, concepts, and criteria that adversely affect the consideration of reactor safety. Most of these, according to the report of the counsel general, are remnants from the AEC. The findings of this report served to support the recommendation of the Kemeny Commission that the permitting and licensing process should be so reformed as to prevent major financial resources of a utility from being 
committed to the construction of a nuclear facility prior to the resolution of relevant safety problems.

The NRC shares with other independent regulatory commissions the shortcomings of a collegial system of administration in which the chairman of the regulatory body is but a first among equals. Although the NRC does have an executive director for operations, his authority vis-a-vis that of the commission is not adequately defined in the Energy Reorganization Act of 1974. Furthermore the EDO is legally restrained from preventing the directors of certain offices in the NRC from reporting directly to the commission. Although the Act has been amended to provide that he be supplied with written reports concerning such communications, the EDO cannot initially affect the contents of these communications.

The lack of effective communication between commission and its staff is ascribed, in the counsel general's report, to both the breadth of the NRC ex parte rules and agency policy discouraging informal contact between individual commissioners and the commission staff. These two factors, according to the report, result in a lack of meaningful communication between the commission and its staff to the detriment of rational policymaking that could implement the charge of the NRC to protect the public health and safety.

The two-step procedure in the licensing of nuclear reactors by the NRC has come into disfavor both because it is a source of unnecessary delay and because it entails no effective design 
safety review. Such a trenchant observor as Harold Green has suggested that there is no real justification for the reguirement of an operating license for a nuclear reactor. He advocates that an effective construction permit process would meet the needs of a rational system for licensing reactors. (1)

Another criticism of the licensing process charges that generic safety issues are not perceived as reasons for denying construction permits or operating licenses. In this connection, it is alleged that unresolved safety concerns that arise in the course of a licensing proceeding are redefined as "generic" issues and removed from the licensing process.

NRC design review is limited to "single failure" and "safety related" analyses. This requires neither planning nor review of safeguards for accidents that entail multiple system or component failures. Furthermore, there is a disinclination on the part of the NRC either to require retrofitting or ratcheting to reflect design safety requirements developed after the plant is built or after the permit application is filed. Finally, it is alleged that the NRC allows plants to obtain operating licenses despite open safety issues.

J. Criticism of NRC Design Basis Review

Several of the criticisms of the NRC have particular relevance to the development of an appropriate regulatory

(1) "Public Participation in Nuclear Power Plant Iicensing: The Great Illusion," 15 William and Mary Law Review 503 (1974); "The Nuclear Power Licensing Mess," 33 Record of the Association of the Bar of the City of New York 489 (1978) 
structure for a fusion reactor industry. From this perspective, the most important of these are: (1) the issue of generic safety problems; (2) design review limitations; (3) the problem of ratcheting and retrofitting.

The generic safety issue is related to the 1972 policy of standardization adopted by the AEC. The implementation of this policy involved a generic approach to the licensing of nuclear reactors. This requires the resolution, in separate rulemaking proceedings, of issues common to nucleár facilities generally. As of 1974, four such generic hearings have been completed. They concerned the design of the emergency core cooling systems, power plant effluents, the uranium fuel cycle and the transportation of fuel and waste material (Trosten and Moore, "Nuclear Power Plant Standardization: Promises and Pitfalls," 15 William and Mary Law Review 527 (1974)). Trosten and Moore contend that the generic hearing process allows public interest groups and utilities to concentrate their technical and financial resources in a single proceeding relating to nuclear reactor design, thereby leading to improved decision-making and the formulation of a standardized design intended to enhance public health and safety.

The NRC's characterization of certain safety issues as generic and its attempt to resolve these matters in generic rulemaking proceedings had the effect of foreclosing consideration of these problems during the application process. Whatever may have been the intention of such generic proceedings, the NRC's removal of these safety questions from the application 
processes would not appear to be justified. At one point, for example, more than 200 safety issues were being ignored during licensing proceedings on account of their generic classification. Nevertheless, generic rulemaking can lead to significant improvements in the licensing process if utilized to promote design standardization based upon the latest available scientific knowledge. It has definite applicability to a fusion reactor regulatory structure since it can provide a sound basis for the adoption of rules and regulations governing the design of such reactors.

NRC's current practice regarding design review has three components: (I) the concept of "safety-related" design factors; (2) design basis analysis; and (3) single failure analysis. Only "safety related" components of a reactor's design are reviewed to determine whether they will perform as intended. This approach begs the question as to the meaning of "safety related." A much sounder approach is to review the design in its entirety to determine whether it will function as intended.

In its design basis analysis, the NRC utilizes nine classes of occurrences ranging from class 1 or trivial incidents to class 9, a hypothetical accident that is more severe than the loss of coolant accident postulated in a class 8 incident. Prior to the TMI II accident, class 9 events were not considered by the NRC in safety analyses to establish performance requirements of reactor

(I) Counsel general's Report To The Kemeny Commission, p. 45 
safety components and systems. These events were excluded from the design basis analysis for the reason that they are perceived to be low probability occurrences. This design basis safety approach assumes either that all potential accidents are put into the design basis for complete mitigation or remain outside it and have no safeguards. A more realistic approach is to assume a spectrum of accidents, each with a probability and consequences of its own. This permits analysis of the probabilities of each occurrence and the consequences that flow from its taking place. (Note: the NRC may be retreating from its present policy of refusing to consider class 9 accidents in its design basis analysis. The NRC recently announced (l) that it was establishing an interim policy of considering class 9 accidents in preparing EIS's.)

In the design basis analysis, the NRC excludes from consideration lesser events that are not considered a serious threat. The justification for this approach seems to be that the analysis of a more serious event of necessity takes into account any lesser event of the same kind. This assumption has been questioned as early as 1969 by an AEC internal study group. It has been suggested that there are qualitative differences between certain small accidents and larger accidents of the same type for which the design criteria are suited. For example, a very small break loss of coolant accident is different from a

(1) Atomic Energy Clearinghouse, Vol. 26, No. 25, June 27, 1980,
p. 74 (2) Counsel general's Report To The Kemeny Commission, p. 68 
large break accident of the same nature. Thus, designing against the large break loss of coolant accident does not necessarily prevent a smaller accident from progressively deteriorating into a serious event.

Single failure analysis serves to limit severely the scope of design review. A single failure is defined by the NRC as an occurrence that results in a component's inability to perform its intended safety function. Multiple failures resulting from a discrete occurrence are considered a single failure. Design safety review based on the single failure hypothesis assumes that the failure of a particular system will not be aggravated by other random failures. Thus, by a series of limiting design assumptions as to safety, the NRC excludes from consideration occurrences that may have substantial impact upon reactor safety.

K. Summary of Criticism of the NRC

From the foregoing critique of the operations of the NRC in its licensing and regulatory functions, it is fair to conclude that the NRC does not provide a viable structure for the regulation of fusion reactors. Moreover, it currently does not have regulatory jurisdiction over such reactors. Iithium is not defined in the Atomic Energy Act of 1954 as "source material." Tritium, which is produced from lithium, has not been determined by the commission to be a "special nuclear material" (and thereby subject to regulation by the NRC) in accordance with the provisions of the Atomic Energy Act of 1954. 
To determine that a substance other than one enumerated in the statutory definition is a "special nuclear material," the commission must make a finding that the material is capable of releasing substantial quantities of atomic energy and, furthermore, must find that all uses of such material should be strictly controlled in the interest of the common defense and security. In addition, the President must expressly assent in writing to the commission's determination. The determination of the commission and the assent of the President are then to be submitted for approval to the Congressional successor to the Joint Committee on Atomic Energy. If this committee fails to act to the contrary within a thirty day period the determination of the commission becomes effective. See Section 51 of the Atomic Energy Act of 1954,42 U.S.C. Section 2071.

It is clear that this section of the Atomic Energy Act is intended to elaborate a process by which nuclear material with a capability of releasing a substantial amount of atomic energy is to be determined special nuclear material for reasons of national defense and security. Nuclear materials that do not have such capability and that are not specifically named in the statutory definition of "special nuclear material" would seem to be free from the licensing requirements of the NRC.

If the regulation of fusion reactors were to be placed under the jurisdiction of an agency other than NRC, revisions would be required in the statutory definitions of source material and special nuclear material to exclude from NRC's statutory authority 
any possibility that it would be able to assert licensing and regulatory power over fusion reactors. However, since tritium has military applications, any legislation specifically establishing an agency for the licensing and regulation of fusion reactors would, of necessity, be required to contain provisions regarding national defense and security.

The accident at Three Mile Island resulted in renewed public concern regarding the capability of the NRC adequately to regulate nuclear reactors in the interest of public health and safety. The report of the Kemeny Commission and other bodies investigating the accident (and the factors that may have contributed to $i t)$ revealed the NRC to suffer from the classic infirmities of an independent regulatory commission. Moreover, the structure and personnel of the NRC in large measure was inherited from the $A E C$, which was subject to much critical analysis by those concerned with the environment and public health and safety.

One of the major infirmities of the NRC is its application of ex parte principles. The ex parte principle is well understood as an aspect of an adjudicatory process. Adjudication must proceed on the basis of a record that contains the necessary and sufficient evidence upon which a decision is based. The adjudicatory process is compromised if matters, not of record, are utilized in the decision-making process. However, ex parte rules should have limited application to functions of an agency that are not adjudicatory in nature. The extension of ex parte rules 
to situations that do not functionally require them serves to inhibit meaningful planning and policymaking within an agency.

In addition to the ex parte rules of the NRC, the collegial process by which it performs its other responsibilities, inciuding the general administration of the agency, is counterproductive to good administrative and personnel practice. Matters of budgeting, personnel administration and the like are better performed, in general, if responsibility for those functions is lodged in one person, rather than a collegial body.

Finally, the concepts utilized by the NRC in evaluating the design of nuclear facilities are such as to put a premium upon semantically ambiguous definitions and doubtful hypotheses rather than upon incorporating the more realistic probabilistic analysis to establish design review criteria.

For these reasons, any attempt to model a regulatory structuro for fusion reactors upon the structure of the NRC would be ill advised and not in the public interest. Rather we believe the regulatory structure should be headed by a single individual who is vested with all administrative and enforcement authority and who serves at the pleasure of the President and whose appointment is subject to the advice and consent of the senate. This regulatory structure should be within the Executive Branch of government and could either be an administrative agency, a commission whose chairman is the single individual described above, or a hybrid structure in which the Executive Agency has an Advisory Board attached to it. In either of the latter two cases the board or commission would have no administrative or enforcement powers, but would play a 
significant role in the formulation of regulatory policy and the adoption of rules and regulations. This board or commission would consist of members appointed by the President with the advice and consent of the Senate to serve fixed but staggered terms, and could allow the balancing of political interests found in many existing independent regulatory commissions. However, the power vested in the single individual should allow for more efficient administrative practices, provide for more meaningful enforcement, facilitate the formulation of long range policy and make the proposed structure somewhat more responsive to the political process, as compared with the present situation with fission reactor regulation.

In particular, since neither the single administrative head of the body nor the members of the board or commission would be "Judges" in adjudicatory hearings or appeals, there would be no conflicts with their responsibility in developing policy due to ex parte rules stemming from such a dual position, as is currently the case for the NRC Commissioners. As such this structure could allow policy formulation to be evolved in a collegial manner, without attendent problems stemming from diffuse administrative and enforcement authority coupled with restrictions resulting from ex parte rules. 
IV. CONSIDERATIONS RELEVANT TO A FEDERAL AGENCY

FOR THE REGULATION OF FUSION REACTORS

Any recommendations regarding a regulatory structure for the fusion reactor industry must consider the nature of the fusion process, the purposes of the regulation, the regulatory tools and approaches available, the manner in which the regulatory process is to function, the structure of such an agency, and the degree of particularity that the congressional delegation of authority to such agency should contain.

A. Relevant Technical Aspects of Fusion

Basically, the fusion fuel cycle (assuming the deuteriumtritium (D-T) reaction) involves the chemical preparation of lithium, which is then introduced into the fusion reactor together with an initial charge of tritium and deuterium. The D-T reaction is then utilized to produce high energy neutrons whose capture in the reactor blanket provides the heat to power electrical generators. The neutrons produced in the D-T reaction also combine with the lithium to produce additional tritium to sustain the reaction. While this fuel cycle is much simpler than that of fission and self-contained to a much greater degree, there are a number of environmental and safety areas with which regulation must deal. Assuming that lithium mining and preparation are dealt with in a conventional manner, the principal areas in question are accidental releases of radioactivity, radioactive waste management and disposal, proliferation of nuclear weapons, routine releases of radioactivity during normal operation (principally tritium), and occupational safety and health. The 
following text very briefly reviews these hazards with comparison to fission systems where relevant.

\section{Accidents}

Since very little tritium and deuterium are present in the reactor core at any one time, the maximum credible accident which a fusion reactor presents is far less severe than that possible in a fission plant. Moreover, the radioactive inventory in a fusion reactor is mostly contained in the reactor's metal walls (rather than the fuel rods as in a fission reactor) where it would be largely immobilized unless an accident also subjected this material to very high temperatures or pressures, which is highly unlikely. The exception is the tritium fuel, whose biological hazard potential is many times less than that of fission products such as radioactive iodine, strontium, cesium and actinides found in the fuel of fission reactors.

\section{Radioactive Waste Management and Disposal}

The fusion reaction produces very high energy neutrons that strike the reactor walls and induce radioactivity in the structural materials. It has been estimated that the walls of a 1,000 megawatt fusion reactor may contain between 1 to 10 billion curies of radiation. However, this radioactivity decays much more rapidly than that produced in the core of a fission reactor, and its half-life varies substantially depending upon the alloys used as structural materials. Nevertheless, the high energy neutrons will damage the reactor walls so that it will be necessary to replace them at regular intervals. Depending upon the type of metals ultimately used in the reactor vessel, these irradiated materials must be isolated from the environment for a 
span of years of unknown length. The magnitude of the span could be just a few years but could also be several hundred years. In the best case, the structural materials could be kept on site and recycled in a short period of time. Thus, fusion power waste management may be easily hanaled or may turn out to present difficulties similar to those of fission energy.

3. Proliferation of Nuclear Weapons

Pure fusion systems do not produce fissile material (e.g., plutonium) in routine operations, and thus do not present a direct route to nuclear weapons proliferation. The fusion neutrons could be used to breed fissile material through insertion of fertile material (e.g., $\mathrm{u}^{238}$ ) in the blanket, but a fusion reactor is not particularly attractive as such a neutron source. Since tritium is relatively easy to produce and handle compared to highly enriched uranium and plutonium, the major proliferation risk for fusion is the spread of knowledge. But this risk is focused primarily in the inertial confinement (laser) approach to fusion. The magnetic confinement systems under consideration in this report are not relevant to fusion weapons development. A fission-fusion hybrid reactor, i.e., one that both produces fusion power and breeds fuel for fission reactors, would present similar proliferation risks as fission breeder reactors.

4. Routine Releases of Radioactivity The principal environmental concern associated with the routine release of pollutants from a fusion reactor is the control of tritium. The tritium inventory in a D-T reactor is 
such that containment of one part in $10^{6}-10^{7}$ would be necessary to keep releases down to projected levels of ten curies per day, or a few millirems per year dose to individuals living near the reactor site. Tritium has a relatively short environmental halflife of 12 years, and releases very low energy radiation with little penetrating power. Thus the hazard to man from tritium external to the body is negligible. However, tritium can form the analog of water, HTO, and be captured in the body. Body residence time in such a case is approximately 12 days. The few millirems per year dose mentioned above would occur in this way and is well below the maximum dose of .5 rem per year recommended by the ICRP.

\section{Occupational Safety and Health}

Fusion reactors lead to concern for occupational safety and health in three areas. These are: (1) occupational exposure to tritium; (2) personnel exposure to strong magnetic fields, a subject about which little is known; and (3) exposure by workers to neutron-induced radiation from the reactor walls and blanket during regular reactor maintenance. Housekeeping procedures will have to be specifically designed for fusion reactor workers to avoid problems in these areas.

Legislation intended to address the regulation of fusion reactors must take into consideration the known risks and benefits of this technology and formulate a regulatory regime adequate to the task involved in such regulation. It must contain both substantive and procedural provisions intended to 
minimize environmental and occupational health and safety hazards and articulate a process of regulation that can gain public confidence.

B. Adjudicatory Considerations in the Regulation of Fusion Power

Current practice of the NRC requires that a public adjudicatory hearing take place before a construction permit is issued. The same is true with regard to the issuance of an operating license. Putting aside for the moment the issue of whether there should be two-step application process, consideration may be given to the issuance of a construction permit prior to any hearing whatsoever.

In doing so, it is necessary to compare the present processes with those that might be found in new legislation appropriate to fusion reactor regulation. When an application for a construction permit is ready for hearing, the applicant is necessarily a party thereto. Whether NRC staff will participate, as a party to the proceeding, is a matter of policy for staff to determine. The staff may intervene either in support or in opposition to the applicant. The burden is upon the utility to show that the grant of the application has a reasonable expectation of no unreasonably adverse effects upon public health and safety. Other than the applicant and commission staff, any interested party may participate as an intervenor in the hearing process, provided that the party files a timely petition to intervene, which sets forth the petitioner's interest in the 
proceeding, how that interest may be affected by the proceeding, and the issues upon which the petitioner desires to intervene (10 C.F.R. Sections 2.714 (a) (1), 2714(a)(2)). Once permission to intervene is granted, an intervenor may examine, cross examine and subpoena witnesses (10 C.F.R. Section 2.714). The ASLB, before whom the proceeding is held, will issue a permit if it finds that the proposed reactor can be constructed without undue risk to the health and safety of the public and that the issuance is justified by the need for power from the proposed facility, the available alternatives, and relevant environmental, economic and other costs and benefits.

In light of the length of the hearing process, limited work authorizations may be given in appropriate circumstances prior to the issuance of the construction permit. Furthermore, some issues, otherwise relevant to the construction of the facility, may be deferred to the licensing stage. Finally, "generic safety issues" may never be disposed of in either a licensing or construction permit proceeding.

Under this system, the utility must establish its entitlement to a construction permit. The staff of the Commission is not required under this procedure to make a determination as to whether the permit should be granted other than its recommendation contained in its final EIS. While this process may seem to place a heavy burden upon the utility, in reality, much time and money is consumed in a needless hearing process while the utility may be proceeding apace under a limited 
work authorization from the commission. Moreover, substantial sums of money may have been spent by the utility prior to the filing of a construction permit application and during the hearing process on the construction itself so that only the most cogent and overriding health and safety issues may justify refusal to grant a construction permit.

\section{c. One Process Considerations in the * Permitting Process}

There are no constitutional barriers to a procedure whereby a decision upon the construction permit application may be made without a prior adjudicatory hearing. The fifth amendment to the Constitution provides, among other things, that no person shall be deprived of life, liberty or property without due process of law. Thus, it is the "deprivation" of a right or entitlement that requires procedural due process. Bell v. Burson, 402 U.S. 535 (1971). From this perspective, a process could be elaborated whereby an application for a construction permit was filed, reviewed for conformity with regulatory stand... ards, and acted upon prior to any adjudicatory hearing. Thereafter, an interested party who had requisite standing could require review of the decision by an administrative hearing board, the decision of which would constitute a final order for purposes of judicial review.

Such a process would justify a statutory requirement that no construction be started prior to the issuance of a construction permit. The law then could provide for an adjudicatory hearing 
by an aggrieved party within a certain specified time. If the action were the grant of a permit, statutory provisions may provide for the issuance of a stay upon a preliminary showing of substantial and irreparable harm and a failure of the licensing body to comply with regulatory requirements in its action. Barring such a preliminary showing, the permitee at its peril could begin construction under the permit. Under such a system, the review board would not be responsible to the administrative head of the body in the decision-making process and would be barred from making ex parte communication with litigants before it. However, the licensing body itself would not be subject to the ex parte requirement. This would facilitate internal communication in the review and decision making processes and contribute to more rational data collection, evaluation, and better policymaking.

D. Recommended Permitting Approach, Modification, and Ratcheting

To be workable, such a system would require that the filing and disposition of applications for construction permits be published in the Federal Register and that the entire record culminating in the decision be available for inspection. It should also require that the decision set forth in detail the reasons for its action. Review of the action upon petition by an aggrieved party should be to determine whether the initial action was justified. The burden should be on the licensing body to show that its action was in conformity with the enabling legislation and the rules and regulations adopted pursuant thereto. 
The enabling legislation should specifically authorize the administrative head of the regulatory body to impose permit conditions and to order such design and construction modifications, after the original issuance of a permit, as may be required to protect the public health and safety. The legislation should also provide that, except for modifications proposed by the applicant, no modifications may be imposed upon the utility except those ordered by the administrative head or his delegate. (1) The utility would be able to contest such orders for modification in the same manner and to the same extent as any other aggrieved party. Upon a preliminary showing by the licensing body that the ordered modifications are necessary for public health and safety, the burden of proof shall shift to the utility.

If any proceeding before the Review Board, a party may challenge the applicability of health and safety regulation and design criteria to the specific circumstances. However, the party so challenging the applicability of the regulations or criteria shall have the burden of proof with respect to this consideration. Under such a system, decision making would be more expeditious and, in all likelihood, more thorough than is now the case. Furthermore, in the administrative review proceeding upon petition of an aggrieved party, it would be the licensing body's action that would be reviewed. Thus, it is likely that the initial decision would be more responsible than is the case where review is

(1) The Act will authorize the administrative head of the regulatory body to delegate his responsibilities to certain named officials. 
to determine whether the utility met its burden of proof. Since the decision of the Review Board, under such a system, would constitute final action for purposes of judicial review, the time and expense wasted on a multi-layered administrative review process would be obviated.

E. Probabilistic Analysis and Rule Making Procedures The enabling legislation for an agency that would regulate fusion reactors should establish legislative standards of substantive and procedural nature to be followed by the agency. The substantive standards should embody a direction to the agency to employ probablistic analysis to the design criteria for fusion reactors. It should also require the agency to review a design for a fusion reactor from a total engineering perspective so that artificial categories of review are eliminated. Environmental and occupational health and safety standards should not be adopted without consultation with EPA and the National Institute of Occupational Safety and Health (NIOSH). If the respective standards of the agency differ from those recommended by EPA or NIOSH the agency should be required to set forth in writing its reasons therefor.

The enabling legislation for the agency should establish a rulemaking process similar to that embodied in Executive Order 12044 in order to promote wide public participation in the rulemaking process and to assure that periodic review of the rules is undertaken. Moreover, the legislation should encourage the adoption of generic rulemaking with regard to standardized reactor design. Since in any construction process involving complex technology 
design changes are likely to occur throughout the process for various reasons, the generic regulations, to the extent possible, should provide for those design changes that will not require a modification of the construction permit and those that will. Those design changes that require amendment of the existing construction permit should not go into effect before an application for such amendment has been approved. Similarly, any aggrieved party should be able to petition for review of the amendment and be restricted to questioning the propiety of the grant of the amendment. The petitioner should not be permitted on an amendment to question the validity of the unamended permit. 


\section{RECOMMENDATIONS}

On the basis of the foregoing, it is recommended:

(1) Any body regulating commercial fusion reactors should be a single federal entity in the Executive Branch of the Federal Government. The regulatory body should have as its head a single individual who serves at the pleasure of the President, with appointment of this individual subject to the advice and consent of the senate. This regulatory structure could either be an administrative agency, a commission whose chairman is the single individual described above, or a hybrid structure in which the Executive Agency has an advisory board attached to it. In either of the latter two cases the board or commission would have no administrative or enforcement powers, but would play a significant role in the formulation of regulatory policy and the adoption of rules and regulations. This board or commission would consist of members appointed by the President with the advice and consent of the senate to serve fixed but staggered terms, and could allow the balancing of political interests found in many existing independent regulatory commissions.

(2) The regulatory body should have the power to delegate to qualifying state agencies such enforcement, inspection, and monitoring activities as are necessary to determine whether Federal standards are being met. The statute authorizing such delegation should be written so as to provide that, except for the limited delegation, the Federal Government shall preempt the field with regard to the construction and operation of fusion reactors.

(3) The Atomic Energy Act of 1954 and the Energy Reorganization Act of 1974 should be so amended as to preclude the NRC from exercising any regulatory authority whatsoever over fusion reactors.

(4) The regulatory body should have specific legislative authority to grant, deny, grant subject to conditions, revoke, or suspend construction permits for fusion reactors. 
(5) The enabling legislation should provide a rulemaking process similar to that established by Executive order 12044. Such rulemaking should provide for the adoption of rules and regulations establishing standards for environmental and occupational health and safety, the design criteria for fusion reactors, and rules and regulations for the general administration and enforcement of regulatory responsibilities.

(6) All design criteria regulations should be based upon a legislatively required standard of probabilistic safety analysis.

(7) The legislation should specifically provide for compliance with the requirements of NEPA with regard to rulemaking that sets environmental, occupational or design standards.

(8) Regulations promulgated by this regulatory body shall be subject to judicial review as to the manner of their adoption, their compliance with NEPA regulations, and compliance with the provisions of the enabling legislation in regard to their substantive content. The court of Appeals for the District of Columbia Circuit shall have exclusive jurisdiction over such cases. The judicial review of regulations shall be initiated within a specific time period subsequent to their promulgation.

(9) Regulation regarding design criteria shall be based upon a prototype reactor developed and tested by DOE. No prototype shall form the basis for design criteria unless the regulatory body shall have evaluated all existing data regarding the development, construction, and testing of the prototype and shall find that the prototype will, if commercially available, not be injurious to the environment, or to public or occupational health and safety. Such an analysis shall accompany all design criteria regulations with regard to a specific prototype.

(10) No application for a Construction Permit shall be accepted for review unless notice thereof is first published in the Federal Register and in a newspaper of general circulation that serves the area in which the proposed fusion reactor is to be located.

(11) The regulatory body shall initially review the application and supporting data and make a determination as to whether the application is complete under the requirements of the Act and the rules and regulations promulgated pursuant thereto. It may reject any application that fails to so conform. 
(12) The application shall include a safety analysis report and an environmental report in sufficient detail to enable a determination as to whether the design criteria of the regulations are met and to enable the application to be subjected to the NEPA review process.

(13) The determination of the regulatory body regarding a permit application shall be published in the Federal Register, and served upon the applicant. Any party whose interest is adversely affected by the determination may petition the Review Board of the regulatory body, to which reference will be made hereinafter, to review the determination in an adjudicatory proceeding. The Review Board may affirm, reverse, modify or remand the application to the regulatory body for further review in accordance with the Board adjudication. The adjudication of the Board shall not be reviewable by the administrative head of the regulatory board but, if it constitutes a final order, it shall be reviewable upon petition to the Federal Court of Appeals of the circuit in which the proposed facility is to be located.

(14) The party seeking review of the grant of the permit before the Board shall be precluded from contesting the validity of regulations, but shall not be precluded from claiming that compliance with such regulations in the specific case is insufficient to achieve the health and safety requirements of the Act. The burden of proving such a contention shall be on the party raising the issue.

(15) The Review Board shall consist of two technically trained persons and one attorney. The Review Board shall not be administratively responsible to the administrative head of the regulatory body and shall refrain from any ex parte communication with the applicant, a petitioner, an intervenor or any enforcement personnel of the regulatory body.

(16) Board review regarding permit applications and retrofit orders, and judicial review of board adjudications shall include a review of compliance of the regulatory body with NEPA.

(17) The regulatory body shall be specifically authorized to consider the funding of petitioners and intervenors in proceedings pertaining to the promulgation of regulations and in proceedings before the Review Board. 
(18) Upon complaint of the regulatory body or any interested party, the Review Board may, after due notice and opportunity to be heard, assess civil penalties for violation of rules and regulations set by the regulatory body of the authorizing legislation.

(19) No construction permit may be suspended or revoked without prior notice of the reasons therefor and an opportunity to be heard before the Review Board.

(20) The regulatory body shall have the authority to order the operation of the fusion reactor to cease prior to hearing before the Board, if such operation constitutes an immediate hazard to public health and safety or to the health and safety of the personnel operating the reactor. The Federal District Court for the district in which the reactor is located shall have jurisdiction to grant an injunction against the operator of the facility upon a certification that the facility constitutes such an immediate hazard. Otherwise, an order to cease reactor operations may issue only upon prior written notice to the operator of the grounds therefor and after a reasonable opportunity to be heard by the Review Board. 
VI. CONCLUSIONS

The above recommendations assume that DOE has developed a prototype fusion reactor that has been thoroughly tested and found capable of being essentially replicated for commercial operation in a manner not injurious to the environment, public health and safety, or occupational health and safety. Moreover, it assumes that the enabling legislation for such a regulatory regime will allow the administration head of the regulatory structure to so structure its offices (other than the Review Board) to accomplish the purposes, goals and objectives of the legislation. It will be noted that, in contrast with the procedures of the NRC, the procedures of the proposed regulatory structure are intended to be less time-consuming and establish a process that is likely to approach fundamental issues in either a rulemaking or adjudicatory process in a more rational manner than is presently the case with the NRC.

By severing the Review Board from the other offices of the regulatory structure and providing for a decision on construction Permit applications prior to any adjudicatory proceeding, the type of confusion that now afflicts the NRC can be avoided. Moreover, by placing the regulatory structure within the Executive Branch, the problems of communication that result from the imperatives of a collegial type independent regulatory agency may be addressed in an administratively rational context. 
The proposed elimination of the operating License requirement is predicated upon the assumption that a well-conceived construction Permit program will obviate the necessity for an Operating Iicense. Furthermore, the regulatory body is proposed to have the authority to impose sanctions upon the operating utility, including a cease and desist order, for violating operating standards required by the Act, its rules and regulations. By providing for the issuance of a Construction Permit prior to any adjudicatory hearing that may be held, justification exists for holding fast to a policy of no construction without a permit. It is intended that no limited work authorizations be issued. Either a permit is granted or no construction may be commenced. The issue of what constitutes a departure from the design authorized by the Construction Permit as to require an amendment thereto is proposed to be addressed in the design criteria regulations. Since it is unrealistic to assume that design changes will not be made during construction, reasonable accommodation to this reality must be made. It cannot with certainty be said how this issue should be resolved, but the process needs to be established in the regulations to determine when an amendment to the permit is required.

Finally, although the problems of retrofitting and ratcheting have not been addressed, it is assumed that any enabling legislation for any body regulating fusion reactors should contain provision to order necessary design changes during construction and to order operating reactors to be retrofitted where health and safety considerations demand such. 


\section{BIBLIOGRAPHY}

1. Pfiffner-Presthus, Public Administration (4th Ed. 1960).

2. Corwin's, The Constitution and What it Means Today (1973 Ed.).

3. K. Davis, Administrative Law Treatise, Sec. 6.17 (1970).

4. United States Commission on the Organization of the Executive Branch of Government, Task Force on Regulatory Commission, "The Independent Regulatory Agencies: A Report with Recommendations" (1949).

5. The President's Advisory Council on Executive Organization," A New Regulatory Framework: Report on Selected Independent Regulatory Agencies" (1971).

6. Subcommittee on Administrative Practice and Procedure of the Committee on the Judiciary, U.S. Senate, 86th Cong., 2nd Sess., "Report on Regulatory Agencies to the President Elect" $(1960)$.

7. Committee on Governmental Affairs, U.S. Senate, 95th Cong., 2nd Sess., "Study on Federal Regulation" (1977).

8. Report of the President's Commission on the Accident at Three Mile Island (1979).

9. Report of the Office of Chief Counsel, President's Commission on the Accident at Three Mile Island, "The Nuclear Regulatory Commission" (1979).

10. Shapiro, The Choice of Rulemaking or Adjudication in the Development of Administrative Policy, 78 Harv. I. Rev. 921 (1965).

11. Cottrell, ECCS Rule-Making Hearing, 16 Atomic Energy LJ 350 (1975).

12. Note, Energy Reorganization Act of 1974: More Power to the People? 7 Loyola ULJ 410 (1976).

13. Note, Environmental Law - Statutory Interpretation - The Environmental Protection Agency Enters the Nuclear Age. 9 Suffolk 1512 (1975). 
14. Note, "Extraordinary Nuclear Occurrence" Threshold and Uncompensated Injury Under the Price - Anderson Act, 6 Rutger's Camden IJ 360, (1974).

15. Lieberman, Generic Hearings: Preparation for the Future, 16 Atomic LJ 141 (1974).

16. Ramey, old and New Concepts in Siting and Licensing Nuclear Power plants, 9 Forum 211 (1973).

17. Symposium: The Nuclear Power Plant Licensing Process, 15 W\&M L ReV. 487 (1974).

18. Grainey, Nuclear Reactor Regulation: Practice and Procedure Before the Nuclear Regulatory Commission, Il Gonzaga L Rev. 809 (1976).

19. Carrow, Dean Landis and the Regulatory Process, 29 Geo. Wash. L Rev. 718 (1961).

20. Peck, Regulation and Control of Ex Parte Communications with Administrative Agencies, 76, Harv L Rev. 233 (1962).

21. Note, Use of Generic Rule Making to Resolve Environmental Issues in Nuclear Power Plant Licensing, 61 Va L Rev. 869 $(1965)$.

22. Montgomery and Rose, Some Institutional Problems of the U.S. Nuclear Industry, Technology Review, March/April 1979.

23. Nesse et al, Economic Costs of Regulation of Thermal Plants, Report to NRC, June 1980, Pacific Northwest Laboratories.

24. EIA Policy Study, Nuclear Power Regulation, May 1980 (DOE/EIA $-0201 / 10)$

25. Golay, How Prometheus Came to Be Bound: Nuclear Regulation in America, Technology Review, June/July 1980. 


\section{DISTRIBUTION}

No. of

Copies

OFFS ITE

$$
\begin{aligned}
& \text { A.A. Churm } \\
& \text { DOE Patent Division } \\
& 9800 \text { S. Cass Avenue } \\
& \text { Argonne, IL } 60439
\end{aligned}
$$

27 DOE Technical Information Center

25 Gene Nardella

Reactor Systems and

Applications Branch

Office of Fusion Energy

Mail Stop G-234

(Germantown Headquarters)

Washington, D.C. 20545

Hans L. Hamester

Donovan, Hamester \& Rattien 1055 Thomas Jefferson St., N.W. Suite 414

Washington, D.C. 20007

Michael Lotker

4720 Montogomery Lane

Suite 302

Bethesda, MD 20014
No. of

Copies
Paul Sommers

Human Affairs Research

Centers

4000 N.E. 41st Street

P.0. Box 5395

Seattle, WA 98105

Molly Selvin

Human Affairs Research

Centers

4000 N.E. 41st Street

P.0. Box 5395

Seatt1e, WA 98105

ONS ITE

DOE Richland Operations Office

H.E. Ransom

24 Pacific Northwest Laboratory

D.E. Deonigi

D.A. Dingee

A.D. Rockwood

L.D. Willi ams

T.L. Willke (10)

Economics Library (3)

Publishing Coordination (2)

Technical Information KE (5) 
